IZA DP No. 8322

Inequality in Total Returns to Work in Ukraine:

Taking a Closer Look at Workplace (Dis)amenities

Olena Nizalova

July 2014 


\title{
Inequality in Total Returns to Work in Ukraine: Taking a Closer Look at Workplace (Dis)amenities
}

\author{
Olena Nizalova \\ Kyiv School of Economics, \\ University of Kent and IZA \\ Discussion Paper No. 8322 \\ July 2014 \\ IZA \\ P.O. Box 7240 \\ 53072 Bonn \\ Germany \\ Phone: +49-228-3894-0 \\ Fax: +49-228-3894-180 \\ E-mail: iza@iza.org
}

Any opinions expressed here are those of the author(s) and not those of IZA. Research published in this series may include views on policy, but the institute itself takes no institutional policy positions. The IZA research network is committed to the IZA Guiding Principles of Research Integrity.

The Institute for the Study of Labor (IZA) in Bonn is a local and virtual international research center and a place of communication between science, politics and business. IZA is an independent nonprofit organization supported by Deutsche Post Foundation. The center is associated with the University of Bonn and offers a stimulating research environment through its international network, workshops and conferences, data service, project support, research visits and doctoral program. IZA engages in (i) original and internationally competitive research in all fields of labor economics, (ii) development of policy concepts, and (iii) dissemination of research results and concepts to the interested public.

IZA Discussion Papers often represent preliminary work and are circulated to encourage discussion. Citation of such a paper should account for its provisional character. A revised version may be available directly from the author. 


\section{ABSTRACT}

\section{Inequality in Total Returns to Work in Ukraine: Taking a Closer Look at Workplace (Dis)amenities}

This paper examines the importance of non-monetary dimensions of work in studies of inequality in total returns to work. Relying on the methodological advances in the field of multidimensional inequality and using the representative sample of Ukrainian industrial establishments over the period from 1994 to 2004, the paper shows that the focus on monetary compensation is too narrow. It ignores significant dynamics of inequality in workplaces. Analysis of such workplace conditions as risk of on the job injury, various benefits/amenities, and insecurities with wage payments, shows that the inequalities in these conditions do exacerbate inequalities in hourly wages. Workers in establishments paying highest hourly wages have enjoyed relatively greater reductions in the total workplace injury burden, greater retention of various benefits/ amenities, and relatively larger increases in wage payment security (decreased wage arrears), compared to the workers in the lowest paying establishments. These findings document the degree of an unequal shift away from work-centered provision of social services and highlight the importance of timely policy intervention.

JEL Classification: J81, D63, C14

Keywords: $\quad$ workplace injuries, disamenities, amenities, non-wage benefits, multidimensional inequality, non-parametric

Corresponding author:

Olena Nizalova

University of Kent

N117 Cornwallis Building

Canterbury, CT2 7NF

United Kingdom

E-mail: o.nizalova@kent.ac.uk

\footnotetext{
* This project has been financially supported by the ERSTE Foundation through the 2013 Fellowship for Social Research. The author is thankful to Nataliia Shapoval, Vadym Bizyaev, and Vladyslav Petrov for excellent research assistance. A special gratitude goes to Tom Coupe for access to the ULFS data, and Elena Korosteleva for fruitful discussions.
} 


\section{Introduction}

More than two decades after the collapse of the Soviet Union, public opinion polls in the New Independent States show that people are unhappy about the state of affairs with political and economic life. These are the same people who, inspired by Western democracies in political realm and superiority of the capitalistic system in the economic domain, voted for independence. For example, in Ukraine $90 \%$ of the population voted for independence in the national referendum in December 1991. Tired of corruption, life in scarcity and deficit, and attracted by the abundance and opportunities, which the Western model offered, people entrusted their lives to the hands of newly formed governments with the hope that this will bring a better life if not for themselves, then for their children. For example, according to the Times Mirror Center survey in the spring of 1991, 72\% percent of Ukrainians supported the change to democratic rule and 54\% showed approval for the movement towards market economy (Pew Research Center, 2011). Twenty years later, according to the same source, only $35 \%$ of Ukrainians approve multi-party system and only $34 \%$ - market economy. About $95 \%$ of Ukrainians think, politicians have benefited a great deal or a fair amount from the changes since 1991, and $76 \%$ say this about business owners. Only $11 \%$ believe that ordinary people have benefited from the change. A great part of the disillusionment may be explained by the increasing inequality in both existing conditions and opportunities.

As Stiglitz (2013) points out, an increasing inequality creates considerable tensions in the society, which may lead to civil movements and attempts by people to correct what went wrong in their countries. The most recent history has provided a number of examples starting from Germany in first half of the 20th century and the Arab spring a short while ago. Since the previous year the protests around the world ${ }^{1}$ have demonstrated the increasing anger of the public and the feeling that inequality has gone too far. The World Economic Forums Global Risk Report rated inequality as one of the top global risks of $2013^{2}$. Even the IMF and the Economist agree on this matter ${ }^{3}$. Adjustments to rising inequality may

\footnotetext{
${ }^{1}$ http://occupywallst.org/

${ }^{2} \mathrm{http}: / /$ www.weforum.org/issues/global-risks

${ }^{3} \mathrm{http}: / /$ www.economist.com/node/21564413, http://blog-imfdirect.imf.org/2011/04/08/inequality-andgrowth/
} 
be applied through a more progressive tax system. But some policy makers argue that the alleviation of tax burden from the rich would eventually lead to the creation of more jobs for everyone (so-called "trickle-down" economics). Yet, a lengthy period of persistent growth in inequality combined with the movement towards a less progressive tax system in the USA and other developed countries, and at the same time worsening of the well-being of the majority of population, has shown that the "trickle-down" simply does not work (Stiglitz, 2013). Moreover, more and more evidence is suggesting that inequality harms the society in many dimensions, which have been out of focus of the economists before. Simple country level comparisons show that countries with higher disparity between the top and bottom quartiles of the income distribution have higher rates of mental illness, drug use, and homicide; a larger proportion of their population is imprisoned and obese; children in these countries are much more likely to drop-out from high school, less likely to experience upward socio-economic mobility, and have, in general, lower level of wellbeing; the level of trust is also lower in these unequal countries (Wilkinson and Pickett, 2010). At the macro level, inequality has also been shown to impede sustainable growth (Ostry and Berg, 2011).

The literature on income inequality has flourished in the first decade of the 21 st century with considerable attention being paid to the methodological aspects of the measurement, decomposition and analysis of the underlying causes of the phenomenon. It should be noted, that researchers' focus has also shifted towards documenting and studying more carefully various non-monetary characteristics of individual and household well-being, from housing conditions and health status to social exclusion. Scholars of social exclusion usually conceptualize it either as the lack of participation in social institutions (Paugam and Russell, 2000; Chakravarty and D'Ambrosio, 2006), or as the denial or non-realization of rights of citizenship (Room, 1995), or the increase in distance among population groups (Akerlof, 1997). Few works have explored the issue of income/wage inequality in Ukraine and Russia (Ganguli and Terrell, 2006; Galbraith, Krytynskaia, and Wang, 2004; Gorodnichenko, Peter, and Stolyarov, 2010; Lokshin and Ravallion, 2005), and found that, if anything, the change in inequality after 1995 has been quite modest. But does the measure used in the earlier studies reflect the true inequality levels in the society? Is there anything 
important missing from the picture? This paper tries to address this question and explore whether the non-monetary dimensions of work can explain the growing tensions in the society where the changes in income/wage inequality have been quite modest. The study of non-monetary working conditions is important for several reasons.

First, work is central to people's lives not only because major share of the household income in most countries comes from earnings (Guerriero, 2012), but also because individuals spend a considerable part of their time at work. Thus, as Rosen (1986) points out, the conditions in which people work do matter and they constitute part of the total compensation to work individuals obtain. Rosen's (1986) theory shows that riskier jobs have to be compensated by higher wages, while more pleasant working conditions can be obtained at the expense of lower wages. Taking Rosen's theory a step further, Hamermesh (1999) shows that the increasing wage inequality may lead to a situation when high wage earners would opt for safer working environment by giving up part of their ever-growing wage, while low-wage earners may, in fact, choose riskier jobs to secure somewhat higher earnings, as the price of risk increases. Therefore, empirically, the observed persistent increase of the earnings inequality can be either mitigated or exacerbated by the trends in the non-wage compensation. Thus, rising earnings inequality can inappropriately reflect the true level of the total inequality in the labor market. Moreover, there is some evidence that even in the absence of the relationship between working conditions and individual wages, like in the Finnish labor market, adverse working conditions substantially increase the level of job dissatisfaction and the perception of unfairness of pay at the workplace (Bockerman and Ilmakunnas, 2006).

Second, the importance of this direction of research is further highlighted by the development of the ILO "Decent work agenda". One of its aims is to promote both inclusion and productivity by ensuring that women and men enjoy working conditions, which satisfy several criteria. They are safe, allow adequate free time and rest, take into account family and social values, provide for reasonable compensation in case of lost or reduced income, and permit access to adequate healthcare ${ }^{4}$.

Third, inequality in working conditions, and in particular workplace injuries, may di-

\footnotetext{
${ }^{4}$ http://www.ilo.org/global/about-the-ilo/decent-work-agenda/lang-en/index.htm
} 
rectly translate into income and wealth inequality, and, indirectly, affect inequality in future generations. For example, Marquis and Manning (1999) find that in the USA worker's compensation in case of on-the-job injury replaces only 32 to 41 percent of 10-year pretax losses. These large losses lead injured workers to borrow money, sell their cars, move to less expensive housing or even sell a home (another venue for the impact on children's future outcomes), draw down their savings, and so on (Keogh et al., 2000). These losses are not compensated by the increased involvement of injured workers into household production. In fact, 40 percent of injured workers reduce their household work by 1 or more days and 11 percent report that they no longer could do housework. Moreover, a substantial number of injured workers require care during recovery - increasing time demands on other family members (Hensler et al., 1991). Moreover, if low wage earners are working during inconvenient hours, are more bound to shift type of employment, experience greater insecurity in wage payments and greater risks of on-the-job injury, while having fewer possibilities for training, health care, and less access to childcare facilities, this may jeopardize opportunities for their children as well. This type of employment would mean that people are in general more likely to be tired, less healthy and more likely to become disabled, making it less likely that their children would get proper educational and health investments and, thus, reinforce the inequality in the future.

Finally, as one of the few works on transition countries (Senik, 2009) shows, the most important reference group for people in transition countries are former school mates and colleagues and that the most important negative welfare impact comes from the deterioration of one's own standard of living and from under-performing relative to these two reference groups. Therefore, inequality in workplaces concerns one of these two important reference groups. If this is true for the monetary dimension, this may be relevant for a non-monetary job characteristics as well. This is in contrast to Western European countries where the comparison with family members and "others", but not the colleagues, hurts most and prompts a demand for income redistribution (Clark and Senik, 2010).

This paper investigates whether the inequality in non-monetary workplace conditions exacerbates the inequality in monetary compensation in Ukraine. It contributes to the literature in several ways. First of all, it expands the inequality literature by taking the method- 
ology developed in the area of mutli-dimensional inequality and health inequity and applying it to the study of non-monetary aspects of jobs - workplace amenities and disamenities. Second, it represents the first attempt to measure the inequality in workplace (dis)amenities in one of the FSU countries and compares its time dynamics to that of monetary work compensation. Third, and most importantly, it documents the degree of an unequal shift away from work-centered provision of social services - the phenomenon which has not been addressed by the state in the social policy reforms. Furthermore, it highlights the importance of the development of the multi-dimensional measure of inequality in total returns to work addressing two important peculiarities of the setting under consideration - the need to combine the measures of both amenities and disamenities and the fact that for some of the indicators data contains a considerable number of zeros.

Establishment level data from the Ukrainian Labour Flexibility Survey for the period 1994-2004 is used in the analysis. The available measures of workplace risks include the following: incidence of injuries, average duration of injuries, total number of workdays lost due to injury. In addition, various other job amenities and disamenities are considered, such as number of working shifts, housing subsidies, prevalence of wage arrears, provision of rest houses, paid health services, and others.

The analysis shows that establishments, which pay higher wages, tend to provide safer and, in general, better working conditions than establishments, which pay lower wages. In addition, the latter are much more likely to experience difficulties with the payment of wages and have higher percentage of workers with severe (more than 3 months) wage arrears. A further distributive analysis has shown that the burden of workplace injuries, measured as total work days lost due to injuries per 100 Full Time Equivalent (FTE) employees, over time has shifted from being concentrated in the top part of the wage distribution to the lowest part. Moreover, the distribution of employer-provided benefits has also changed from being almost equally spread across the wage distribution to being more concentrated in the upper part. And this result is not driven by any one particular amenity it is observed across the whole range of indicators. Similarly, wage arrears' concentration has changed from being almost equally distributed across all wage levels to being more concentrated among lower paying establishments. The non-parametric regression results 
go in line with the other approaches - wages tend to be positively associated with amenities, negatively with wage arrears, and the relationship between wages and total injuries is virtually non-existent. Analysis of distributional shifts in the establishment characteristics over corresponding period shows significant changes only with respect to the firm size and export status, and some sectoral shifts.

The remainder of the paper is structured as follows. Section 2 is devoted to the literature review followed by the theoretical considerations in Section 3. Data description is provided in Section 4. Section 5 presents the results. Section 6 is devoted to the discussion of policy implications followed by the conclusions.

\section{Related Literature}

From the economic perspective, inequality is simply the difference between individuals or groups of individuals or populations in the distribution of assets, wealth, income, or any other measure of well-being. This paper focuses on inequality in returns to work taking into account the fact that they consist not only from monetary compensation but also from various amenities and disamenities. This is important because the workers spend a considerable amount of time at work; and the working conditions, and workers satisfaction with them, may have serious consequences for his/her future physical and emotional health and, as a result, future well-being. Since the literature on inequality in workplace conditions is quite scarce, this review will focus more broadly on the wage inequality literature and the developments in the measurements of multiple inequality as most relevant for the chosen empirical strategy.

The literature on wage inequality has mostly been preoccupied with the factors, which have contributed to the increase in wage inequality at the end of the 20th century. This literature has been quite rich, but sometimes contradictory. For example, Levy and Murnane (1992) and Goos and Manning (2007) argue that wage inequality growth has been caused by skill-biased technology developments: e.g. the invention of computers had eliminated many middle-income routine jobs and made the upper-tail wage inequality grow faster ( $\mathrm{Au}-$ tor, Levy, and Murnane, 2003). In line with these studies, Autor, Katz, and Kearney (2008) 
show that the information technology exacerbated polarization in wage distribution at the expense of middle class. However, Card and DiNardo (2002) find only weak evidence of skilled-biased technology to be responsible for inequality growth of 1980-1990s. According to them and other authors (Bound and Johnson, 1992; Viscusi and Aldy, 2003), the transformation of economic institutions could have also contributed to the observed phenomenon. Effects of globalization, trade liberalization and immigration have been considered by Borjas, Freeman, and Katz (1997). Trade liberalization, on the one hand, shapes the industrial composition of the economy and, therefore, defines how intensively the country uses labor-capital factors of production and, hence, influences demand for different types of skills. On the other hand, globalization may create the inflow of the labor of either high, or low skills. Interestingly, exogenous determinants of various skills migration have been shown (Borjas, Freeman, and Katz, 1996) to be insufficiently influential to account for more than a small proportion of the overall increase in wage inequality.

Another part of the literature considers changes in the wage distribution due to underlying changes in the distribution of population groups (Autor, Levy, and Murnane, 2003; Goos and Manning, 2007; Autor, Katz, and Kearney, 2008). Autor, Katz, and Kearney (2008) use time series models in order to disentangle demand-side, supply-side and institutional factors in their impact on educational wage differentials and overall wage inequality. They find that the increased inequality in wages in the USA over the period 1963-2005 is in line with the skill-biased technical change hypothesis - information technology complements highly educated workers engaged in abstract tasks, substitutes for moderately educated workers performing routine tasks, and has less impact on low-skilled workers performing manual tasks.

Although, the wage data is readily available in many countries, earlier research have shown, albeit not always persuasively with respect to all job characteristics (Brown, 1980; Biddle and Zarkin, 1988; Rosen, 1986; Viscusi, 2004; Quintana-Domeque, 2011), that workers may be compensated for (dis)amenities on the job by higher (lower) wages. And, thus, ignoring these aspects of workplaces, may result in misleading conclusions. Therefore, a more comprehensive measure of total returns to work maybe warranted in the studies of inequality in labor markets. 
Some authors in the past looked at the overall job satisfaction (Hamermesh, 2001; Clark and Oswald, 1996) as a measure of total returns to work. Yet, this measure has been criticized as the workers' job satisfaction is influenced by the opinion of the peers and by the expectations the worker formed prior to joining the job. Thus, the distribution of job satisfaction may not necessarily reflect the distribution of total returns to work. Other authors have tried to quantify total returns to work by attaching monetary value to various benefits provided by employers, such as leave benefits, pension payments and health insurance. These studies find that in the United States the inequality in these measures of total compensation has been growing faster than the inequality in wages (Pierce, 2001; Chung, 2003). However, there exists a considerable number of job characteristics, which are not easily quantifiable in monetary terms. So, the only strategy for a researcher is to investigate the dynamics of each of the available job characteristics and reach the conclusion based on the overall evidence.

Hamermesh (1999) follows this route and explores whether the rising wage inequality overstates or understates the true extent of the change in overall inequality in returns to work by considering the non-wage aspects of work which are difficult to quantify. Extending Rosen's (1986) Theory of Equalizing Wage Differentials, he finds empirical evidence that the increasing wage inequality over the period from 1979 to 1995 in the USA have coincided with the declining relative risk in high wage industries and a relative increase in the likelihood of disamenity of night/evening work in low-wage industries.

Similar to the literature on returns to work, the literature on overall household income/expenditure inequality has long suffered from narrow focus on monetary dimension. Although justified by data availability and methodological developments at the time, scholars in development economics have realized the multidimensional nature of inequality and poverty and expanded the necessary methodology. Sen's $(1985 ; 1992)$ calls for alternative approaches targeting the inequality of capabilities to achieve valuable functionings that make up our lives, and more generally, our freedom to promote objectives we have reasons to value, got methodological and empirical attention.

An expanding literature on multidimensional inequality indices has gradually followed in the coming years (Maasoumi, 1986; Maasoumi and Jeong, 1985; Maasoumi and Nickels- 
burg, 1988; Tsui, 1995; Koshevoy and Mosler, 1996, 1997). The information from multivariate distribution has been converted into real-value measurement both through welfarist (Maasoumi, 1986) and nonwelfarist (Tsui, 1995, 1999) approaches. Conventional measures of inequality have also been adapted for the multivariate case: Lorenz curve and Lorenz order gave birth to multivariate generalizations - Lorenz zonotope (Koshevoy, 1995), Lorenz zonoid and Lorenz surface (Koshevoy and Mosler, 1996). Gini indexes have also been extended to multivariate case (Koshevoy and Mosler, 1997). With the growing attention to health inequities in relation to socioeconomic status of individuals, the analogues of the regular instruments for measuring socioeconomic inequality appeared also in the health field (Wagstaff, van Doorslaer, and Paci, 1991; Kakwani and Bank, 1980).

This paper contributes to the inequality literature in several dimensions. First, it improves on the previous literature on inequalities in workplace (dis)amenities by relying on a firm-level (in contrast to industry-level) data set which describes a wide range of job characteristics. Second, it applies the distributional analysis apparatus developed for the study of multidimensional inequality in a new setting of workplace (dis)amenities. Finally, it studies the inequality in overall returns to work in one of the Former Socialists countries, where the population sentiments towards equality are still high and the danger of growing inequality in any dimension should not be underestimated, and where changes in wages and workplace conditions have been caused by major institutional changes, not the changes of underlying population/establishments characteristics.

\section{Theoretical Background and Empirical Strategy}

This paper refers to the standard compensating wage differentials theory developed by Rosen (1986) and further explored with respect to the dynamics of wage inequality by Hamermesh (1999). Comparing a low-wage earner to a high-wage earner who face a differential exogenous change in full earnings, Hamermesh (1999) arrives at the conclusion that we may observe an increasing inequality in workplace amenities between these workers for the following reasons. The increase in the real wage observed throughout low-wage and high-wage sectors has two effects - income and substitution. As amenity is assumed 
to be a normal good, income effect of increasing wages ensures that workers consume less of disamenity (more of amenity). But the "rising return to accepting risk generates a price [substitution] effect that leads him/her [low-wage worker] to accept more of the disamenity [less of the amenity]" (Hamermesh, 1999, p.1090, p.1089).

The overall effect of the increased real wages will depend on the relative size of the two effects - income and substitution - as they are of opposite directions. Since the wage growth for high-wage earners has been disproportionately greater than that for low-wage earners, Hamermesh (1999) argue that the income effect would dominate for the former while the latter will observe dominating substitution effect. As a result, a compression of differences in risks between the two groups of workers will be observed with a corresponding increased dispersion in the wage distribution. Or, as Hamermesh (1999, p.1090) states, those workers whose earnings are falling (rising) relative to those of the average worker will also find their burden of the disamenity rising (falling) relative to that of the average worker, provided that the degree of relative risk aversion is not decreasing in full earnings. For the purpose of this study, all that is required is an exogenous shock generating changing differentials in earnings and in distribution of amenities. This seems to be a very reasonable assumption for Ukraine as during the considered period labor market changes had mostly been driven by political will, not by changing workers preferences and characteristics.

To investigate whether the dynamics of inequality in workplace (dis)amenities exacerbates or mitigates the wage inequality, two approaches are taken. First is the graphical analysis similar to that of Hamermesh (1999) and the second is the distributive analysis following the multi-dimensional inequality literature.

To analyze the distribution of wages and workplace amenities and disamenities, first all of the establishments in the sample are ranked according to the level of hourly wages paid to regular workers. Then the characteristics and the wage level of the average establishment in the first quartile of the wage distribution are determined. Then the difference between log wage of a particular establishment and that of the average lowest quartile establishment is obtained for each of the establishments in the $2 \mathrm{nd}$, 3rd, and 4th quartiles. Concerning the other job characteristics, the ratio is taken between the actual measure of the characteristic and the average establishment in the 1st quartile. The averages of these ratios and their 
time dynamics are then depicted on the graphs for further visual analysis.

While the quartile analysis is somewhat informative, the distributive analysis offers wider opportunities of exploring the associations between movements of monetary and non-monetary aspects of returns to work depending on the place of the establishment in the wage distribution. This part makes use of the Distributive Analysis STATA Package (DASP) (Araar and Duclos, 2007) to:

- Study time dynamics of the Lorenz curve and the concentration curves for three dimensions of work: total workplace injury burden, amenities score, and prevalence of wage arrears;

- Estimate the corresponding concentration indices to see whether the situation is significantly different from the $45^{\circ}$ line, and explore overtime dynamics;

- Estimate the differences between the concentration coefficients over time and analyze the timing of the change.

In addition, the paper offers a non-parametric lowess smoothing to analyze whether there has been a change overtime in the joint movement of wages and the three non-wage dimensions of work considered in this paper, as well as an attempt to construct a hybrid index by estimating multidimensional inequality indices (Araar, 2009) for wages and other non-monetary job characteristics and analyze its time dynamics. The analysis is followed by the discussion of possible reasons behind the changes in inequality and corresponding policy implications.

\section{Data Description}

Ideally, the question of inequality in total returns to work is to be studied using a matched employer-employee data to allow controlling for workers preferences and job characteristics. This data is not available for Ukraine. But this study does represent an improvement over Hamermesh (1999) in terms of data use as it relies on the establishment level information from the Ukrainian Labor Flexibility Surveys for the years 1994, 1996, 1999, 2002, 2004 initiated by the International Labour Organization. This data set is the 
only longitudinal survey of Ukrainian industrial establishments, which provides comprehensive information on the average characteristics of the firms and workplaces, including wages, workforce, injuries, working time, shifts, and other amenities. It should be pointed out that the data was available also for the year 2000, but the measures of wages in this year were totally off reasonable pattern and it has been decided to drop this year from the analysis. This issue is discussed later in the Results section.

The ULFS started in 1994 as part of the collaboration of the ILO with the State Statistics Office of Ukraine surveying a random sample of industrial establishments in six regions of Ukraine: Kyiv City, Kyiv Region, Donetsk, Kharkiv, Lviv and Mykolyiv. By 1999, the survey covered all the regions of Ukraine, thus, providing an unbalance sample of industrial establishments for research analysis. As in other flexibility surveys conducted by ILO, ULFS is based on the interviews with senior managers and two questionnaires, one completed by the establishment, the other administered orally in discussion with managers, often accompanied by senior staff (Standing and Zsoldos, 2001).

The ULFS provides a number of measures for earnings, including separately for employees, regular and non-regular workers. As workers are the ones who are more likely to be exposed to the risk of injury on the job, this paper relies on the measures of earnings for regular workers. So, earnings in each establishment in each year are computed as the sum of full-time equivalent average monthly earnings, overtime pay, and bonuses for establishments, where a positive number of working hours in the past month has been reported. However, the analysis relies on the hourly wage rate calculated from the above-described measure and the total number of hours (including overtime) in the previous week multiplied by four. Figure 2 offers a comparison of the average monthly wage as reported in the ULFS (weighed by the number of workers) and various measures of monthly wages as derived from the National Statistics. ${ }^{5}$ Although it is difficult to find a comparative measure and the data overlaps only for a couple of years, it is obvious that the growing trend is similar. Yet, one should be careful as the composition of industry groups in the National Statistics does not correspond to those in the ULFS. For example, highest paying industry

\footnotetext{
${ }^{5}$ Accessed at http://ukrstat.org/uk/operativ/operativ2006/gdn/prc_rik/prc_rik_u/dszpPD_u2005.html on May 19, 2014.
} 
sector - energy production and supply - is combined with water supply, which is bringing the average down considerably. At the same time, the overall industry measure contains mining, which is not part of the ULFS, and the composition of the "other" group is not clear.

Concerning the measures of (dis)amenities, the main variables of interest are: (i) INC - number of work related accidents per 100 Full-time equivalent workers, (ii) DUR - the average duration of injury in workdays, and (iii) TOTINJ - the total number of days lost due to lost-workday injuries per 100 FTE workers. These three measures and other workplace (dis)amenities are presented in Table 1 along with the corresponding summary statistics by year.

\section{Empirical Findings}

\subsection{Graphical Analysis}

Figure 1 offers a first glance into the overall dynamics of real wages and workplace accidents. As could be seen, the real wage grows from USD 50 (UAH 90) per month in 1996 to about USD 100 (UAH 525) in 2004 and USD 316 (UAH 2517) in 2011. At the same time the number of Work accidents per 1000 Employees decreases from 4.5 to 1.9 in 2004 and 1.1 in 2011, while the same dynamics in fatal workplace accidents is $0.12,0.09$, 0.06. However, the question in this paper is not in the changes to the mean, but how these general trends reflect upon different parts of wage distribution.

To understand the evolution of inequality in earnings over the considered period, a simple measure of standard deviation of the logarithm of hourly wages weighted by the size of the workforce at each establishment is calculated. The second row in Figure 1 presents the time paths of both wage dispersion from the raw wage data and from the residual wage after controlling for regional effects. As the two lines show, most of the dispersion in 1990s is due to the regional wage inequality. Controlling for the latter, the variance of hourly wages is on the decrease from 1994 to 2002, but then starts increasing afterward. The last graph in the second row shows the average differences in log hourly wages between the $2^{\text {nd }}, 3^{\text {rd }}$, and $4^{\text {th }}$ quartiles and the mean of the $1^{\text {st }}$ quartile. Following the 
story with the dynamics of standard deviation, the differences among quartiles are stable before the year 2002 and then increase substantially.

The main question of this paper is whether this relatively stable wage inequality has been exacerbated or mitigated by corresponding changes in inequality in workplace (dis) amenities. Figure 3 illustrates three measures of workplace accidents in the first row. In accordance with the Theory of Equalizing Wage Differentials, the number of accidents is relatively higher in $2^{\text {nd }}, 3^{\text {rd }}$, and $4^{\text {th }}$ quartiles compared to the $1^{\text {st }}$. Similarly, the number of lost men-days per injury has been increasing in relative terms up to year 2002, and in 2004 dropped to almost the same severity for the $2^{\text {nd }}$ quartile, 50\% greater losses for the $3^{\text {rd }}$ quartile and $70 \%$ for the $4^{\text {th }}$ quartile. The total burden of workplace injuries, however, has shown some volatility in the close proximity to the $y=1$ line, with a jump observed for the $4^{\text {th }}$ quartile. This means that in terms of the overall burden of workplace accidents the establishments in different spectrum of wage distribution do not differ. This can partly be connected to the greater availability of the Safety Committees at the establishments in highest quartiles of the wage distribution. Thus, the jobs maybe in general riskier in the higher quartiles of the wage distribution, but better safety measures make the consequences of accidents less severe, and thus lessen the amount of lost men-days.

The similar comparison of the number of shifts per day, shows that the number of shifts is consistently higher in the $2^{\text {nd }}, 3^{\text {rd }}$, and $4^{\text {th }}$ quartiles compared to the $1^{\text {st }}$ one, but it has been on the decline for the $4^{\text {th }}$ quartile from year 1999, and for the other two from year 2002. One may think that the highest wage earners are working longer hours and thus their hourly wage may be higher. Last graph in Figure 3 shows that hours are the same across the whole distribution and across time. And, if anything, top paying establishments had regular workers working $10 \%$ fewer hours compared to the lowest paying ones in years 1994 and 1999.

Another feature of the transition period in Ukraine and other FSU countries was the irregularity of payments, or wage arrears. Therefore, Figure 3 offers graphical analysis of several relevant measures available in the survey. First of all, as could be seen from the first row of the Figure, while at the beginning of the period all of the establishments had similar likelihood of having difficulty with paying wages to their workers, the situation 
changed already in 1995 for the establishments in $3^{\text {rd }}$ and $4^{\text {th }}$ quartiles, with those in the $2^{\text {nd }}$ quartile joining the trend in 2002. Overall, by 2004, establishments in the $2^{\text {nd }}$ quartile have had $20 \%$ less chance of having difficulty with paying wages, those in the $3^{\text {rd }}$ quartile - $60 \%$, and those in the $4^{\text {th }}$ quartile - $80 \%$. With respect to the actual wage arrears, the picture is a bit messier, but the establishments in the $4^{\text {th }}$ quartile have been consistently on the declining trend since the beginning of the period compared to the $1^{\text {st }}$ quartile and by 2004 have been $75 \%$ less likely to have any wage arrears. Other measures, such as the number of weeks during which wages had not been paid in full (severity of wage arrears), percentage of workers fully paid on time (the opposite of wage arrears), and the percentage of workers with wages not paid in full for more than 3 months (extreme wage arrears), are not available in all of the waves of the ULFS. But what is available supports directly the overall conclusion. Those working in the lowest paying establishments had considerably higher chances of not receiving these low wages, and not receiving them for longer time periods.

Figure 4 is devoted to various characteristics of the workplaces which are usually called amenities or benefits. For some of those, like housing provision, paid health services, subsidized housing rent, subsidized kindergarten, provision of loans, the period from 1994 (and probably earlier) till 1999 had been characterized by relatively equal access by different quartiles of the wage distribution. However, after 1999, for all of the aforementioned amenities an increase in inequality has been documented, albeit in some, like health services, kindergartens, and loan provision, the gap has somewhat decreased from 2002 to 2004. For other benefits, like rest houses, assistance on retirement, pension supplement, and training, growing differences between highest and lowest paying establishments have been observed already at the beginning of the period. With respect to subsidized meals and transportation, the overall picture is less clear.

Figures 5-7 show the distribution of wages, the total burden of workplace injuries and the amenities score. The latter is a simple count of the benefits/amenities provided by the establishments to its regular workers. The highest possible magnitude is 16. One should pay attention to an unusually different distribution of wages in year 2000. The standard deviation in that year increases tenfold and the overall wage levels seem to be very different 
both at the lowest and at the highest parts of the wage spectrum. Thus, it has been decided to exclude this year from further analysis. ${ }^{6}$

The total burden of workplace accidents in Figure 6 is only available starting from year 1995, and is top-coded at 10 per 100 FTE workers. Following the overall national trend, the distribution of total injuries has shifted towards zero with majority of establishments in 2004 not having any men-days lost from workplace injuries. Concerning the workplace amenities/benefits (Figure 7), it is clear that over the considered period there has been a significant decline in their numbers with the distribution in 1994 having quite fat righthand tail, while the one in 2004 resembles a normal distribution.

\subsection{Lorenz/Concentration Curves}

Figure 8 in general reflects the earlier graphical comparisons across quartiles - there has been no significant change in the wage inequality from 1994 to 2004. It seems that all the major changes in wage inequality occurred before this period, and the change must have been rather rapid, if we take for granted the relatively compressed distribution of wages in the Soviet Union.

But wages constitute only part of the total returns to work. And, indeed, the following figures show that other workplace characteristics have continued to change over the period. As Figure 9 shows, at the beginning of the period the total burden of workplace injuries had been mostly concentrated among the establishments paying the highest wages. The concentration of the total burden has been decreasing at the top spectrum of wages and increasing at the bottom. And in 2004, the concentration curve flips over the $45^{\circ}$ line, meaning that starting from that year most of the overall total injury burden is shifted to the establishments paying lowest wages.

The third dimension has been compressed to one linear measure of the simple amenities count for the sake of simplicity in further distributional analysis. As concentration curves

\footnotetext{
${ }^{6}$ The changes in the labor legislation and tax codes have been analyzed. However, it seemed unlikely that any of those could have resulted in such a short-lived increase in dispersion of wages, while no similar changes observed in either total injuries or the amenities score. An inquiry has been sent to the responsible office in the ILO to understand possible faults in the data collection during this particular year, but before a clear explanation is found for such a drastic change in the wage distribution, this year could not be used in the analysis.
} 
for the period in Figure 10 show, in 1994 they had been equally allocated across wage distribution. However, starting from 1995, and more noticeable from 1999, the concentration shifts towards right-hand part of the wage distribution with some clear signs of inequality started being observed.

Finally, wage arrears in 1994 are concentrated among the lowest and middle parts of the wage distribution. In 1995 they become almost equally distributed. However, by the end of the observed period they become highly concentrated in the lowest part of the wage distribution (Figure 11).

\subsection{Time Dynamics in Lorenz/Concentration Indices and Hybrid Mul- tidimensional Inequality Index}

Table 2 mirrors the graphical distributional analysis described in the previous subsection with standard errors attached to the concentration indices. It is clear from this table that the differences from the $45^{\circ}$ line are in all cases, but one (wage arrears in year 1999), statistically significant at $5 \%$ level and less.

Although, one gets a general idea of how the inequality in workplaces changed over the considered period from both graphical analysis and the comparison of concentration indices, it is worth testing whether these changes have been statistically significant. At the moment, there is no ready to use test of statistical dominance of the multidimensional measure of inequality. Therefore, this paper will compare the concentration indices for the three non-wage dimensions one-by-one. As Column (1) in Panel B Table 2 shows, in both, total injury burden and wage arrears, from 1995 to 2004 there has been a significant re-shifting of the concentration from highest paying establishments to lowest paying establishments. At the same time, there has been an increases in the concentration of amenities score among high paying establishments, albeit the magnitude of the shift is much smaller compared to the other two dimensions. The remaining three columns are presented to show the rate of change and its timing. For example, the observed change in the concentration for total injury burden occurred first between years 1995 and 1999, with little change between 1999 and 2002, and with an overwhelming change between years 2002 and 2004. The wage arrears concentration had not changed till year 1999, but then the changes of the 
same magnitude happened over the two remaining sub-periods. Contrary to the disamenities, changes in the amenities score concentration have been gradual, almost of the same size across the three considered sub-periods.

\subsection{Non-Parametric Estimations}

Presented above graphical and distributive analysis is supplemented by the non-parametric estimation presented in Figure 12 with bandwidth of 0.2. ${ }^{7}$ The graphs depict estimates from the lowess smoothing with bandwidth 0.2, only for two years, 1995 and 2004. The idea here is to see whether the relationship between wages and various other dimensions of workplace has changed at the end of the considered period compared to the beginning. The first graph shows that, compared to 1995 when the relationship was quite different in different parts of the wage distribution, in 2004 there is clearly no relation between wages and total injury burden - it is the same across all wage levels. This cannot be said though for other dimensions. Amenities score and wages are obviously positively related, with the only difference between 1995 and 2004 being the downward shift in the overall amenities score, and a negative relationship at very high wage levels. The opposite is true for the wage arrears - wages are negatively related to this characteristic up to a log wage of 3 (approximately $20 \mathrm{UAH}$ ), and then turn to positive relationship. One should be careful though with putting much confidence into both too low and too high wages when considering the nonparametric estimates, given that the number of observations at both ends is much smaller and may be driven by outliers.

\subsection{Individual Amenities Dynamics}

To better understand the underlying nature of the distributional change in amenities, they have been analyzed individually. Table 4 summarizes the corresponding results while Appendix B offers graphical analysis. The first two columns in the table show concentration indices for the years 1995 and 2004 correspondingly. The significance levels indicate whether certain amenities are distributed significantly differently from the equal distribu-

\footnotetext{
${ }^{7}$ The bandwidth of 0.2 was chosen to follow the data more closely. However, other bandwidths were tried with higher levels resulting in smoother curves but similar overall relationship.
} 
tion. The last column shows the difference in the concentration indices over time and the significance levels here indicate whether the temporal change has been statistically significant.

As can be seen, in 1995 none of the amenities, but the supplement pension, exhibit inequalities, which is understandable given the Soviet egalitarian approach. However, by year 2004 all of the amenities, except for the provision of free or subsidized meals, are unequally distributed, with establishments at the higher end of the wage distribution being more likely to provide various kinds of amenities. Albeit, one should remember that the time dynamics reflects rather an unequal decline in the provision of amenities, than an expansion of them, as the overall generosity of the non-monetary compensation has been decreasing in the economy. As Column (3) shows the inequality has increased along all of the dimensions, except provision of meals and supplement pensions. The former remained equally distributed, while the latter remained highly unequal.

In a word, the evidence suggests that there has been no single driver behind the significant change in the inequality in workplace amenities. Rather this inequality has been rising across all dimensions. However, for two out of the twelve amenities available in the data, the increase has not been statistically significant.

\subsection{Associated Dynamics in Firms' Characteristics}

Since over the studied period Ukrainian economy has experienced considerable structural changes, one may be interested in knowing whether the changes in total returns to work have been accompanied by prominent distributional changes in firms' characteristics. Appendix A provides a summary of the available firms' characteristics and industrial structure of the sample in 1995 and 2004 across wage quartiles. Table 5 shows the concentration indices for various available firms' characteristics and the corresponding temporal change similarly to Table 4. In terms of the firms' characteristics, at the beginning of the period, only the monopoly status ${ }^{8}$ and the share of female workers seem to be distributed unequally. The latter, is more prevalent among lower paying firms, as would be expected.

\footnotetext{
${ }^{8}$ This question is an indicator whether the manager who is being questioned thinks that the firm enjoys any kind of monopoly power.
} 
In terms of the industrial composition, firms in the Energy sector in 1995 tend to be paying higher wages, while those in Engineering and Wood and Paper are at the lower end of the wage distribution.

The situation changes somewhat by year 2004. Yet, the difference in the distributions is statistically significant only in terms of the firm size and its export status - larger firms, as well as those engaged in exports, are observed in the upper part of the wage distribution. Likewise, the change in the industrial structure is only statistically significant for the Energy sector, becoming more equally spread across the wage distribution, and the Light industry and the Food Processing industry with firms concentrating more at the lower end of the spectrum.

In spite of all the shortcomings, generally speaking, there seems to be very little evidence that such a massive change in the distribution of non-monetary job characteristics has been due to a change in characteristics of the firms represented in the sample.

\subsection{Araar's Hybrid Multidimensional Inequality Index}

Panel A in Table 3 presents the estimates of the Araar (2009) hybrid multidimensional inequality index with the corresponding percentages of the contribution of various dimensions to the overall inequality. One should note the difference in measures of workplace characteristics in this table. For the sake of comparison, all of the measures of "bads" are converted into "goods". In particular, the measure of the workplace injury burden is converted into a safety measure and the wage arrears measure is converted into the wage payment security measure or the measure of the absence of wage arrears. Given the significant number of zeros in the measure of the total injury burden, it has been decided to turn to the standardized measures of all of the dimensions used in the estimation of the multidimensional inequality index. As could be seen, the overall inequality in workplaces has been changing from year to year increasing from 0.12 to 0.16 from 1995 to 1999 and then decreasing to 0.11 in 2002 and 0.09 in 2004 . The overall contribution of wage inequality has been fluctuating over time, likewise the contribution of the workplace safety and the wage payment security. At the same time, the contribution of inequalities in workplace amenities to the total inequality has been persistently increasing. 
It is known that the estimates of the MDI are quite sensitive to the choice of parameter $\lambda$. Panel B of Table 3 provides the results of the sensitivity test by setting the parameter $\lambda$ to different values. As could be seen, the estimated results differ considerably for $\lambda=0$ and $\lambda=0.1$. However, they follow the same pattern for any $\lambda=0.5$ or above. In fact, this range represents the most applicable range for the case under consideration. Araar (2009) states that the nature of the components determine the size of this parameter. If the component $k$ is a perfect substitute of the other set of components, it is appropriate to set the $\lambda_{k}$ to zero. In contrast, if the component is a perfect complement, which seems to be the case for some of the dimensions considered here, then $\lambda_{k}$ will converge to one. Setting $\lambda=0.5$ probably leads to the underestimation of the degree of multidimensional inequality if all of the components are perfect complements.

In spite of the robust evidence on the decrease in overall inequality in returns to work over time, Araar (2009) warns against relying on the hybrid multidimensional inequality index when there is an increase in inequality in one of the components and a decrease in the other. Technically defined, the case of Ukraine is of such nature. Moreover, the whole construct of the multidimensional index of inequality should be reconsidered to better tailor the case of total returns to work. Other transformations of the total injury burden and the wage arrears measure have been tested, and the results turned out to be non robust. More theoretical and methodological research into the nature of the considered problem is required to arrive at the proper multidimensional index. Therefore, in this instance, it is recommended to consider the changes in inequality dimension by dimension, what has been done in this paper earlier.

To summarize, the above analysis shows that the inequality in wages, although remained relatively stable over considered period from 1994 to 2004, has been exacerbated by the increasing inequality in workplace risks, wage payment security (i.e. wage arrears), and amenities. 


\section{Discussion and Policy Recommendations}

After gaining its independence in 1992 Ukrainian society moved away from stateowned economy to its own version of market economy characterized by high levels of corruption and a formation of a very pecuniary phenomenon of criminalized oligarchy culminating into a massive social unrest in the winter of 2013-2014. In the process very little attention has been given to the overall well-being of the majority of the population. Leaving aside the reasons of such neglect, be they due to the genuine lack of resources or bold robbery of the public funds, it materialized into an appalling state of affairs in all aspects of social life, without exceptions. Ukraine is in the midst of a severe population health crisis contributing to a rapid population decline. Widespread poverty is aggravated by deteriorating conditions of housing. Many cities are facing the collapse of the utilities infrastructure due to the 20-years poor maintenance and lack of renovation. Lack of childcare infrastructure is mentioned by people as one of the top three reasons for not having children. Absence of quality social care for elderly and those with long-term conditions is contributing to the lowest life expectancy in Europe. And the list can be continued.

This study provides persuading evidence that Ukraine has moved from the model where social support has been provided primarily through the individual's workplace, but the state failed to pick up important social responsibilities. The results clearly show that the wage inequality, although somewhat declining from 1999 to 2004, is exacerbated by a significant and ever increasing inequality in workplace amenities, such as provision of subsidized childcare and health care, housing, recreation, loans, training, transportation, and assistance on retirement. Greater decline in provision of all these amenities among the lowest paid workers coupled with the inability of the state to offer corresponding public alternatives deepens the divide in well-being among various population groups.

Although little can be done to address the causes of such dynamics in the distribution of non-monetary aspects of work, except for, probably, tighter regulation of the workplace safety and timely wage payments, knowledge of these trends is helpful in designing and reforming the overall social policy in the country. For example, four aspects are worth prioritizing in social policy reform - provision of housing, health care, kindergartens, as 
well as training opportunities. The first two would clearly lead to the improvement of the situation with health inequalities, while the latter would be instrumental in improving the productivity of the workforce immediately, through alleviating the childcare burden, and in the long-run by improving educational outcomes and upgrading the skill level. All of the discussed possible routes would lead to the improvement of the quality of human capital, and, thus, greater economic growth opportunities.

\section{Conclusions}

This study investigated the distribution of workplace characteristics, both amenities and disamenities, as pertaining to jobs at different levels of wage distribution. Analysis of the data on Ukrainian firms over the period from 1994 to 2004 shows that establishments which pay high wages tend to provide safer and in general better working conditions than establishments, which pay lower wages. In addition, establishments within the lowest quartile of the wage distribution are much more likely to experience difficulties with the payment of wages and have higher percentage of workers with severe (more than 3 months) wage arrears.

Further distributional analysis has confirmed the graphical analysis. The burden of workplace injuries, measured as total work days lost due to injuries per 100 Full Time Equivalent (FTE) employees, has shifted from being concentrated in the top part of the wage distribution to the lowest part. Furthermore, the distribution of employer-provided benefits has also changed from being almost equal across wage distribution to more favorable towards upper part of the wage distribution, albeit the overtime effect here has been modest. The dynamics of wage arrears goes the same direction - from being almost equally distributed across all wage levels in 1995 to showing increased concentration among lowest paying establishments in 2004. The non-parametric regression results go in line with the other approaches - wages tend to be positively associated with amenities, negatively with wage arrears, and the relationship between wages and total injuries is negative for the very top of the wage distribution.

Overall, the findings in the current paper suggest that although the wage differentials 
in Ukrainian industries have remained relatively stable over the period from 1994 to 2004, the inequality continued its growth in other dimensions. Although, the overall level of risk has been falling over the period, it has fallen disproportionately more in high paying establishments compared to the low paying establishments. Similarly, while the overall level of workplace amenities has been falling, it has fallen disproportionately more among low paying establishments, and this pattern is uniform across all the individual amenities. Moreover, the decrease in the likelihood of having wage arrears has been disproportionately smaller among establishments paying lowest wages.

Preliminary exploration into the causes underlying the documented distributional change, suggests that there are very limited changes in the underlying firms' characteristics and in the industrial structure of the sample. So, there is a significant move of the large firms and firms engaged in exporting towards the upper end of the wage spectrum. Likewise, a shift of the firms in the Energy sector away from the upper end of the wage distribution, and the firms in the Light and the Food Processing industries towards the lower end of the wage distribution.

Although further research on causes of growth in multidimensional inequality in returns to work is required, this study provides two important lessons for research community and policy makers. First of all, it highlights the importance of multi-dimensional approach to the labor market returns, as a focus on monetary compensation only may significantly underestimate the true inequality in the society. Second, it draws attention to the need of developing counter measures by the government when workplace-centered provision of social service is moving towards market economy and liberalization. By prioritizing measures to facilitate provision of affordable housing, health care, kindergartens, as well as training opportunities, the government could mitigate the increasing inequalities. This would allow avoiding significant tensions and conflicts in the society, which is an important pre-requisite for ongoing sustainable development. 


\section{References}

Akerlof, George A. 1997. "Social Distance and Social Decisions." Econometrica 65 (5):1005-1028.

Araar, Abdelkrim. 2009. "The Hybrid Multidimensional Index of Inequality." Cahiers de recherche 0945, CIRPEE. URL http://ideas.repec.org/p/lvl/lacicr/0945.html.

Araar, Abdelkrim and Jean-Yves Duclos. 2007. "DASP: Stata modules for distributive analysis." Statistical Software Components, Boston College Department of Economics. URL http://ideas. repec.org/c/boc/bocode/s456872.html.

Autor, David H., Lawrence F. Katz, and Melissa S. Kearney. 2008. "Trends in US wage inequality: Revising the revisionists." Review of Economics Studies 90 (2):300-323.

Autor, DH, F Levy, and RJ Murnane. 2003. "The skill content of recent technological change: An empirical exploration.” Quarterly Journal of Economics 118 (4):1279-1333.

Biddle, Jeff E and Gary A Zarkin. 1988. "Worker Preferences and Market Compensation for Job Risk." The Review of Economics and Statistics 70 (4):660-67.

Bockerman, Petri and Pekka Ilmakunnas. 2006. "Do job disamenities raise wages or ruin job satisfaction?" International Journal of Manpower 27 (3):290-302.

Borjas, GJ, RB Freeman, and LF Katz. 1996. "Searching for the effect of immigration on the labor market." American Economic Review 86 (2):246-251. 108th Annual Meeting of the AmericanEconomic-Association, SAN FRANCISCO, CA, JAN 05-07, 1996.

. 1997. "How much do immigration and trade affect labor market outcomes?" Brookings papers on economic activity, Brookings Institution. 63rd Conference of the Brookings-Panel on Economic Activity, WASHINGTON, DC, MAR 27-28, 1997.

Bound, J and G Johnson. 1992. "Changes in the Structure of Wages in the 1980s - An Evaluation of Alternative Explanations.” American Economic Review 82 (3):371-392.

Brown, C. 1980. "Equalizing Differences in the Labor Market." Quarterly Journal of Economics 94 (1):113-134.

Card, D and JE DiNardo. 2002. "Skill-biased technological change and rising wage inequality: Some problems and puzzles." Journal of Labor Economics 20 (4):733-783.

Chakravarty, Satya R. and Conchita D'Ambrosio. 2006. "The Measurement Of Social Exclusion."

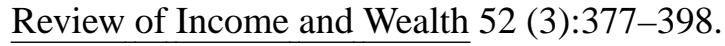

Chung, WY. 2003. "Fringe benefits and inequality in the labor market." Economic Inquiry $41(3): 517-529$.

Clark, AE and AJ Oswald. 1996. "Satisfaction and comparison income." Journal of Public Economics 61 (3):359-381. 
Clark, AndrewE. and Claudia Senik. 2010. "Who Compares to Whom? The Anatomy of Income Comparisons in Europe.” Economic Journal 120 (544):573-594.

Galbraith, James K., Ludmila Krytynskaia, and Qifei Wang. 2004. "The Experience of Rising Inequality in Russia and China during the Transition." European Journal of Comparative Economics 1 (1):87-106.

Ganguli, Ina and Katherine Terrell. 2006. "Institutions, markets and men's and women's wage inequality: Evidence from Ukraine.” Journal of Comparative Economics 34 (2):200-227.

Goos, Maarten and Alan Manning. 2007. "Lousy and lovely jobs: The rising polarization of work in Britain." Review of Economics and Statistics 89 (1):118-133.

Gorodnichenko, Yuriy, Klara Sabirianova Peter, and Dmitriy Stolyarov. 2010. "Inequality and Volatility Moderation in Russia: Evidence from Micro-Level Panel Data on Consumption and Income." Review of Economic Dynamics 13 (1):209-237.

Guerriero, Marta. 2012. "The Labour Share of Income around the World. Evidence from a Panel Dataset." URL http://www.sed.manchester.ac.uk/idpm/research/publications/wp/depp/ documents/depp_wp32.pdf. Working Paper.

Hamermesh, DS. 1999. "Changing inequality in markets for workplace amenities." Quarterly Journal of Economics 114 (4):1085-1123.

36 (1):1-30. "The changing distribution of job satisfaction." Journal of Human Resources

Hensler, Deborah R., M. Susan Marquis, Allan Abrahamse, Sandra H. Berry, Patricia A. Ebener, Elizabeth Lewis, Edgar Lind, Robert J. MacCoun, Willard G. Manning, Jeannette Rogowski, and Mary E. Vaiana. 1991. "Compensation for Accidental Injuries in the United States." RAND Corporation Report Series R3999, Santa Monica, CA: RAND Corporation. URL http://www. rand.org/pubs/reports/R3999.

Kakwani, N. and World Bank. 1980. Income inequality and poverty: methods of estimation and policy applications. A World Bank Publication. Published for the World Bank [by] Oxford University Press.

Keogh, J. P., I. Nuwayhid, J. L. Gordon, and P. W. Gucer. 2000. "The impact of occupational injury on injured worker and family: outcomes of upper extremity cumulative trauma disorders in Maryland workers." American journal of industrial medicine 38 (5):498-506. Research Support, U.S. Gov’t, P.H.S.

Koshevoy, G. 1995. “Multivariate Lorenz Majorization.” Social Choice and Welfare 12 (1):93-102.

Koshevoy, G and K Mosler. 1996. "The Lorenz zonoid of a multivariate distribution." Journal of the American Statistical Association 91 (434):873-882.

Koshevoy, GA and K Mosler. 1997. "Multivariate gini indices.” Journal of Multivariate Analysis $60(2): 252-276$. 
Levy, F and RJ Murnane. 1992. "United States Earnings Levels and Earnings Inequality - A Review of Recent Trends and Proposed Explanations." Journal of Economic Literature 30 (3):13331381.

Lokshin, Michael and Martin Ravallion. 2005. "Rich and powerful?: Subjective power and welfare in Russia.” Journal of Economic Behavior \& Organization 56 (2):141-172.

Maasoumi, E. 1986. "The Measurement and Decomposition of Multidimensional Inequality." Econometrica 54 (4):991-997.

Maasoumi, E and JH Jeong. 1985. "The Trend and the Measurement of World Inequality over Extended Periods of Accounting." Economics Letters 19 (3):295-301.

Maasoumi, E and G Nickelsburg. 1988. "Multivariate Measures of Well-Being and an Analysis of Inequality in the Michigan Data." Journal of Business \& Economic Statistics 6 (3):327-334.

Marquis, M. S. and W. G. Manning. 1999. "Lifetime costs and compensation for injuries." Inquiry : a journal of medical care organization, provision and financing 36 (3):244-254. Research Support, Non-U.S. Gov’t.

Ostry, Jonathan David and Andrew Berg. 2011. "Inequality and Unsustainable Growth: Two Sides of the Same Coin?” IMF Staff Discussion Notes 11/08, International Monetary Fund.

Paugam, Serge and Helen Russell. 2000. "The Effects of Employment Precarity and Unemployment on Social Isolation.' In Welfare Regimes and the Experience of Unemployment in Europe, edited by D. Gallie and S. Paugam. OUP Oxford, 243-264.

Pew Research Center, Pew. 2011. "Confidence in Democracy and Capitalism Wanes in Former Soviet Union." URL http://www.pewglobal.org/files/2011/12/ Pew-Global-Attitudes-Former-Soviet-Union-Report-FINAL-December-5-2011.pdf. Accessed on October 10, 2013.

Pierce, B. 2001. "Compensation inequality.” Quarterly Journal of Economics 116 (4):1493-1525.

Quintana-Domeque, Climent. 2011. "Preferences, Comparative Advantage, and Compensating Wage Differentials for Job Routinization." Oxford Bulletin of Economics and Statistics 73 (2):207-229.

Room, G. 1995. Beyond the Threshold: The Measurement and Analysis of Social Exclusion. Academic Texts Series. Policy Press.

Rosen, Sherwin. 1986. "The Theory of Equalizing Differences." In Handbook of Labor Economics, edited by O. Ashenfelter, R. Layard, P.R.G. Layard, and D.E. Card, v. 2, chap. 12. North-Holland, 641-692.

Sen, A. 1985. Commodities and Capabilities. Elsevier, Oxford.

1992. Inequality Reexamined. Harvard U.P. and Oxford U.P.

Senik, Claudia. 2009. "Direct evidence on income comparisons and their welfare effects." Journal of Economic Behavior \& Organization 72 (1):408-424. 
Standing, Guy and Lszl Zsoldos. 2001. "Worker Insecurities in the Ukrainian Industry: The 2000 ULFS." Working paper, ILO. URL http://www.ilo.org/public/english/protection/ses/download/ docs/2ukraine.pdf.

Stiglitz, J.E. 2013. The Price of Inequality. W W Norton \& Company Incorporated.

Tsui, KY. 1995. "Multidimensional Generalizations of the Relative and Absolute Inequality Indexes - the Atkinson-Kom-Sen Approach.” Journal of Economic Theory 67 (1):251-265.

1999. "Multidimensional inequality and multidimensional generalized entropy measures: An axiomatic derivation." Social Choice and Welfare 16 (1):145-157.

Viscusi, W. Kip. 2004. "The Value of Life: Estimates with Risks by Occupation and Industry." Economic Inquiry 42 (1):29-48.

Viscusi, WK and JE Aldy. 2003. "The value of a statistical life: A critical review of market estimates throughout the world.” Journal of Risk and Uncertainty 27 (1):5-76.

Wagstaff, Adam, Eddy van Doorslaer, and Pierella Paci. 1991. "On the measurement of horizontal inequity in the delivery of health care." Journal of Health Economics 10 (2):169-205.

Wilkinson, R. and K. Pickett. 2010. The Spirit Level: Why Equality is Better for Everyone. Penguin Books Limited. 


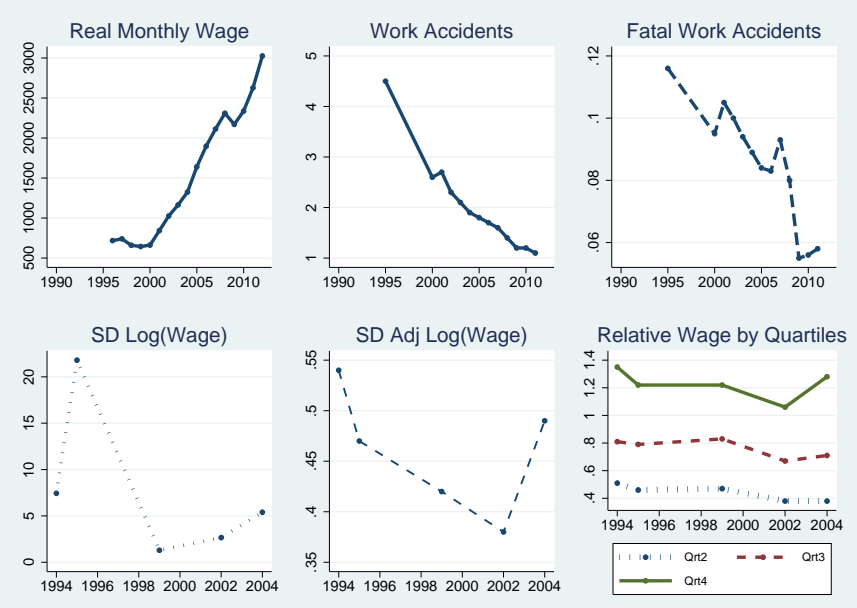

Figure 1: Wages and Accidents (first row - from national statistics, second row - estimates from ULFS)

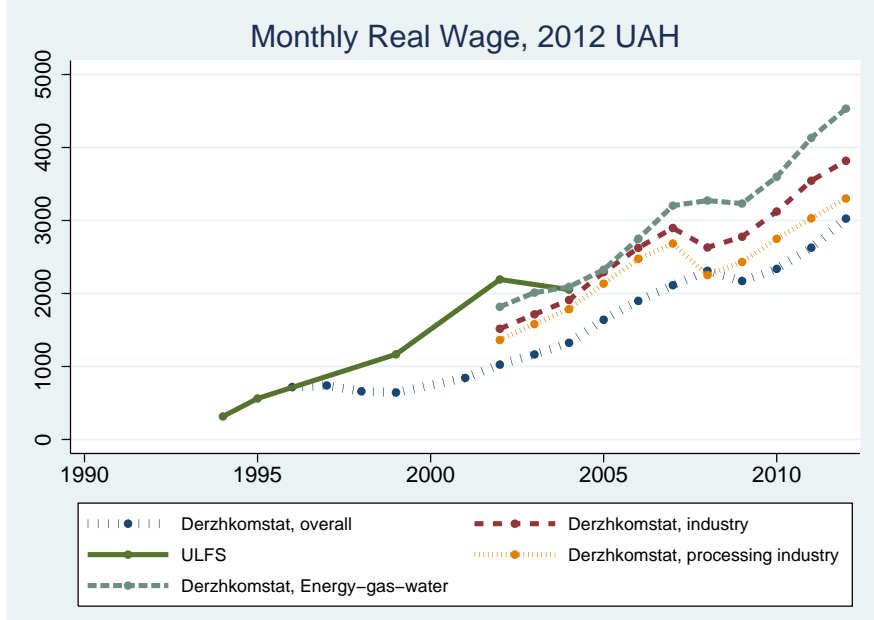

Figure 2: Monthly Wage Dynamics According to Different Data Sources Source: National Statistics. 

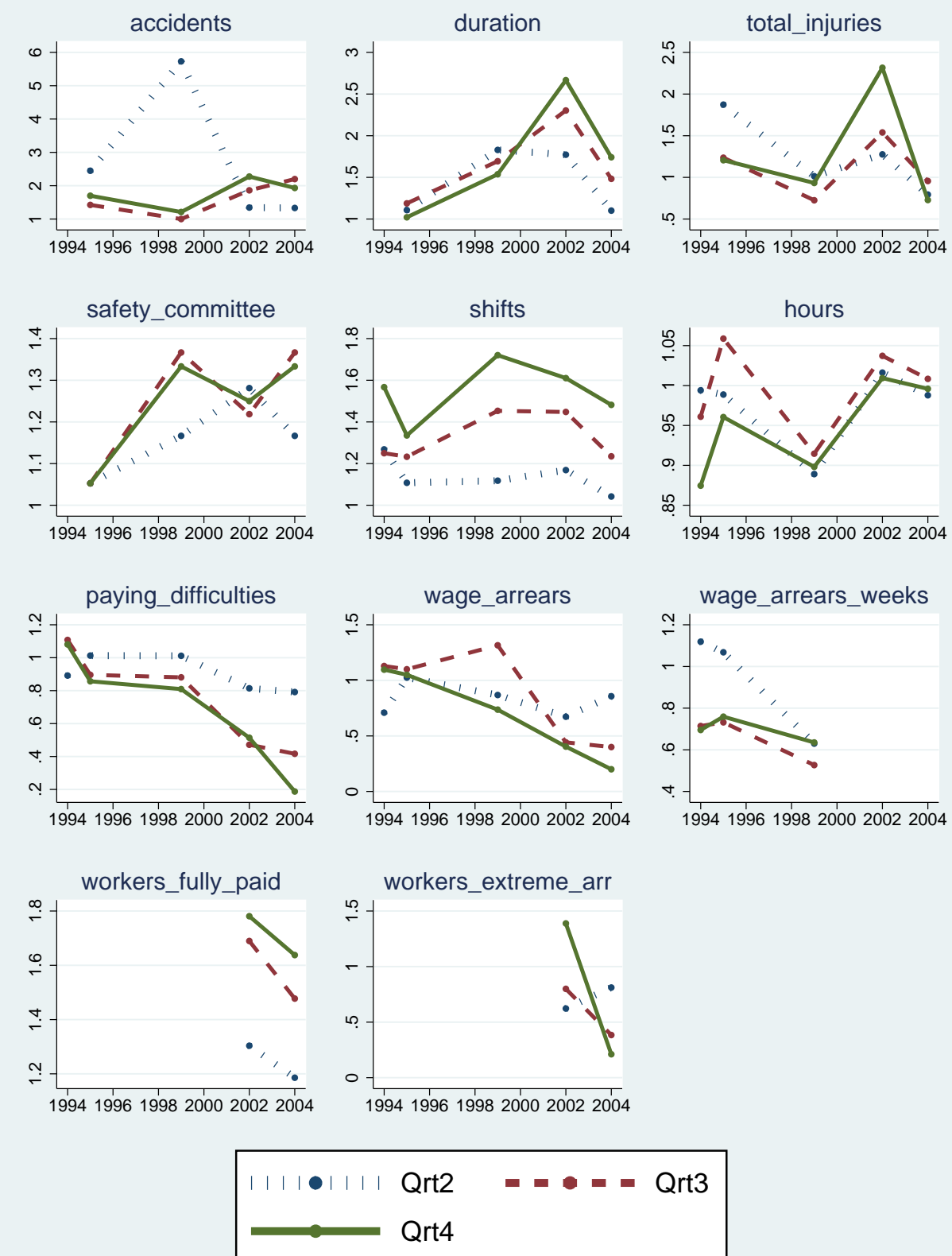

Figure 3: Workplace Risks and Disamenities by Quartiles 

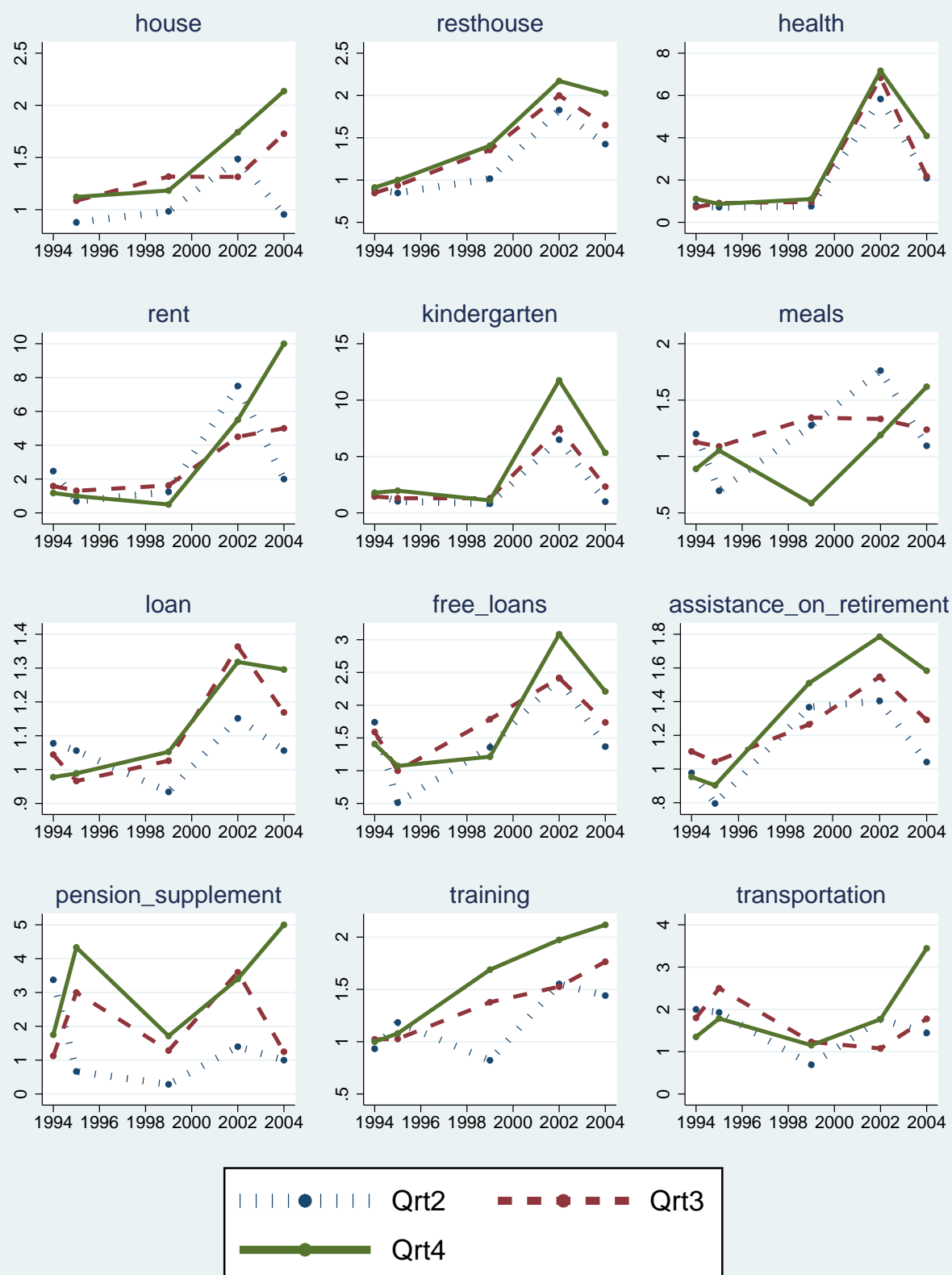

Figure 4: Workplace Amenities by Quartiles 


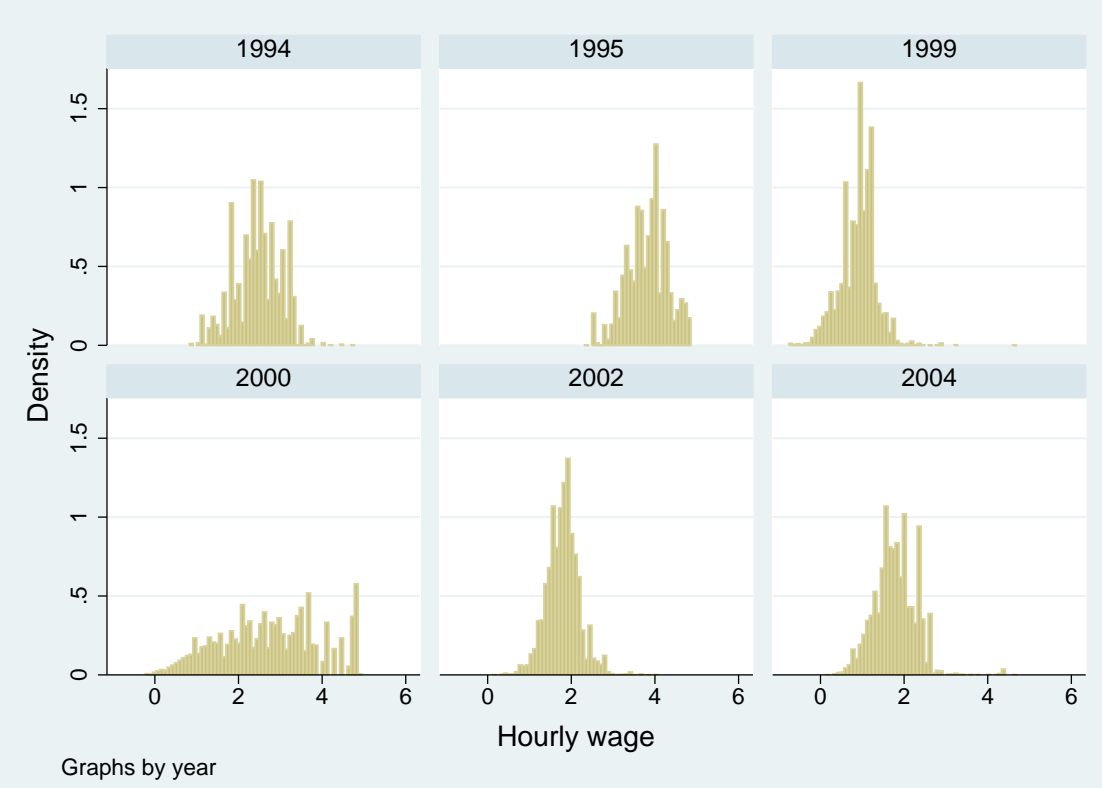

Figure 5: Distribution of Adjusted Wages by Year

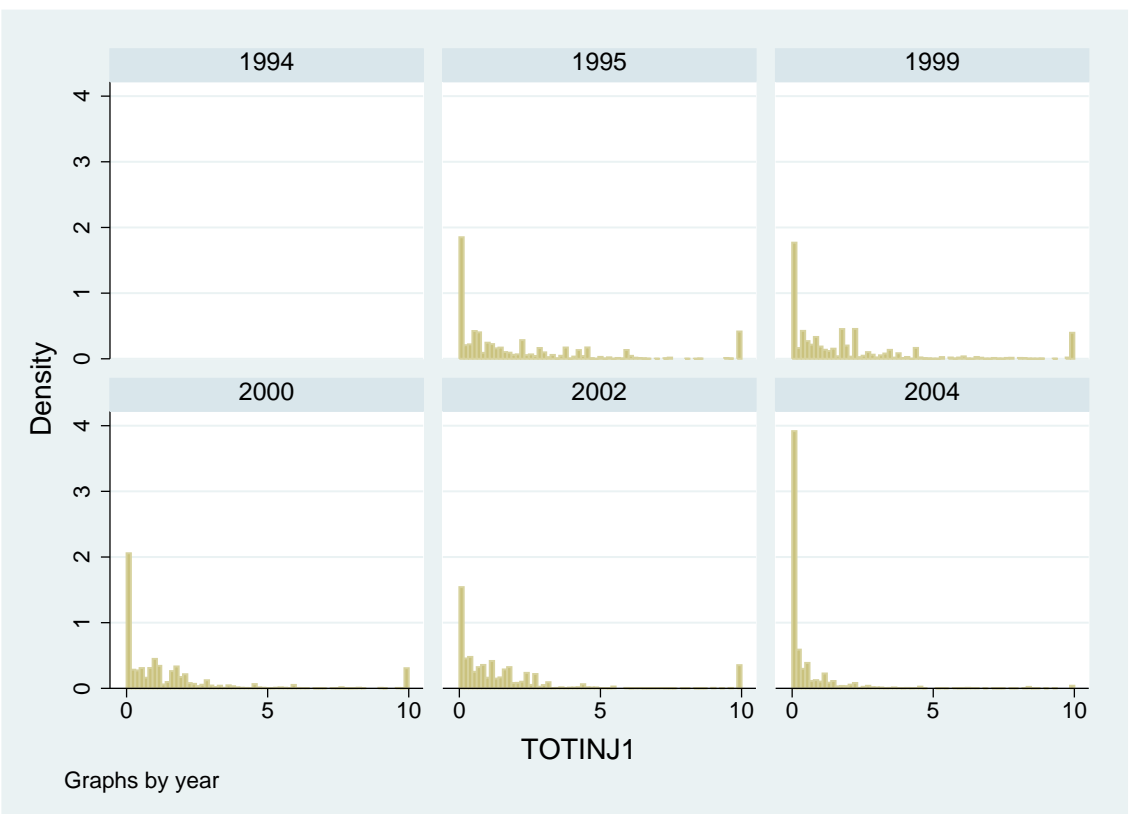

Figure 6: Distribution of Total Injury Burden by Year 


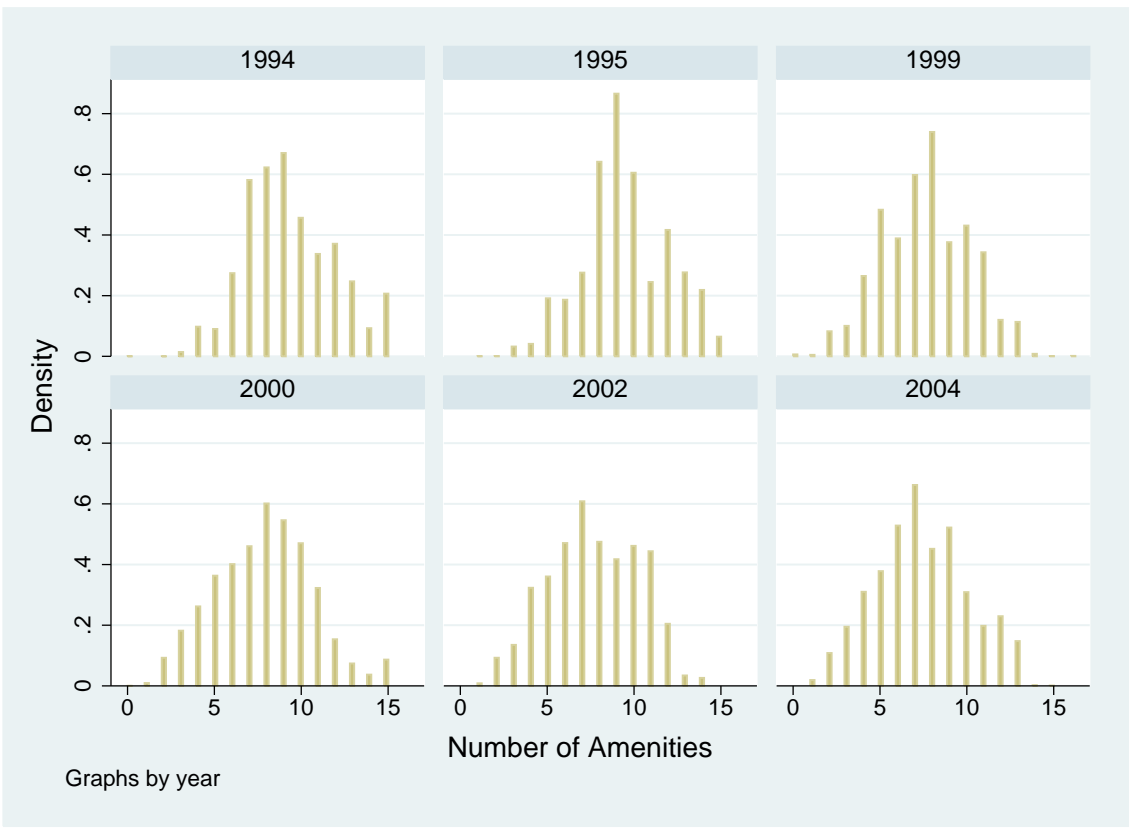

Figure 7: Distribution of Amenities Score by Year

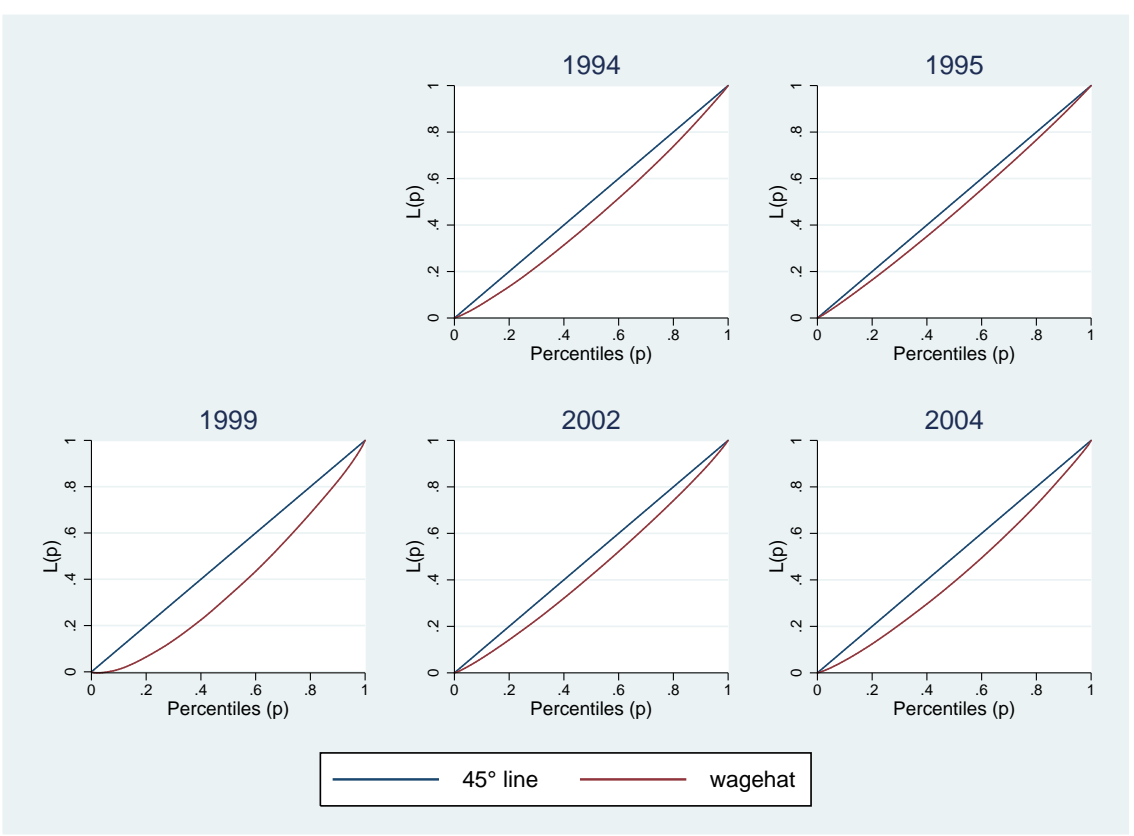

Figure 8: Lorenz Curves - Wages by Year 

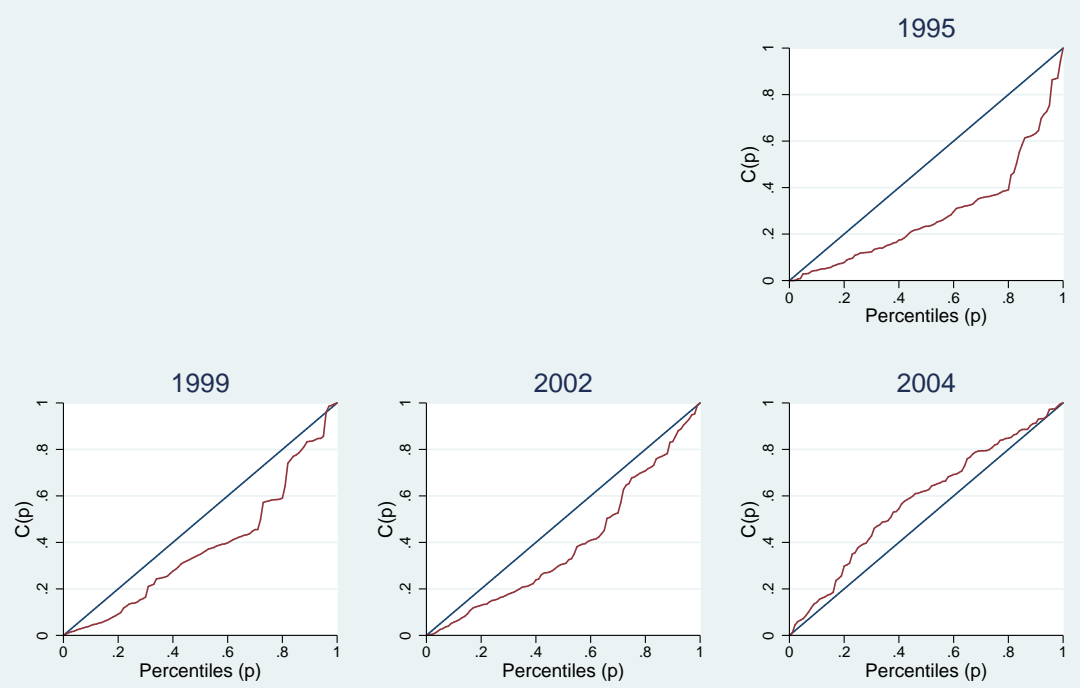

$45^{\circ}$ line TOTINJ

Figure 9: Concentration Curves - Total Injury Burden by Year

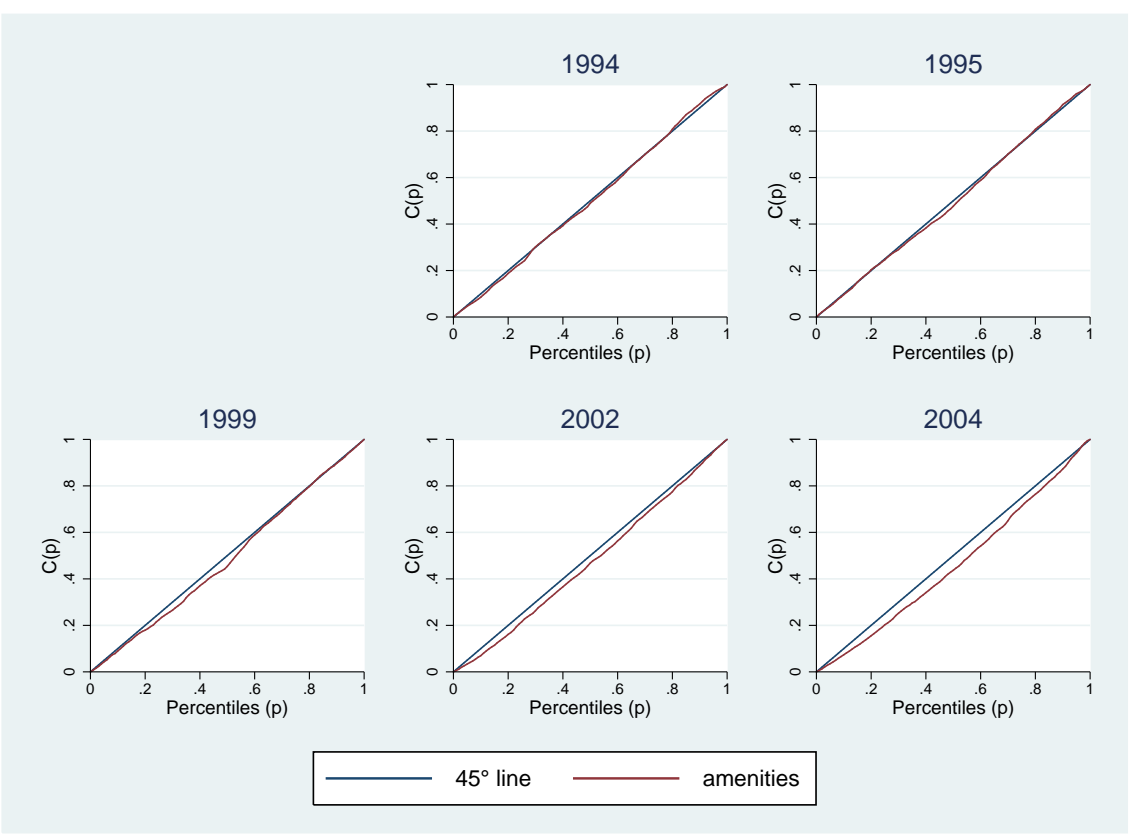

Figure 10: Concentration Curves - Amenities Scores by Year 

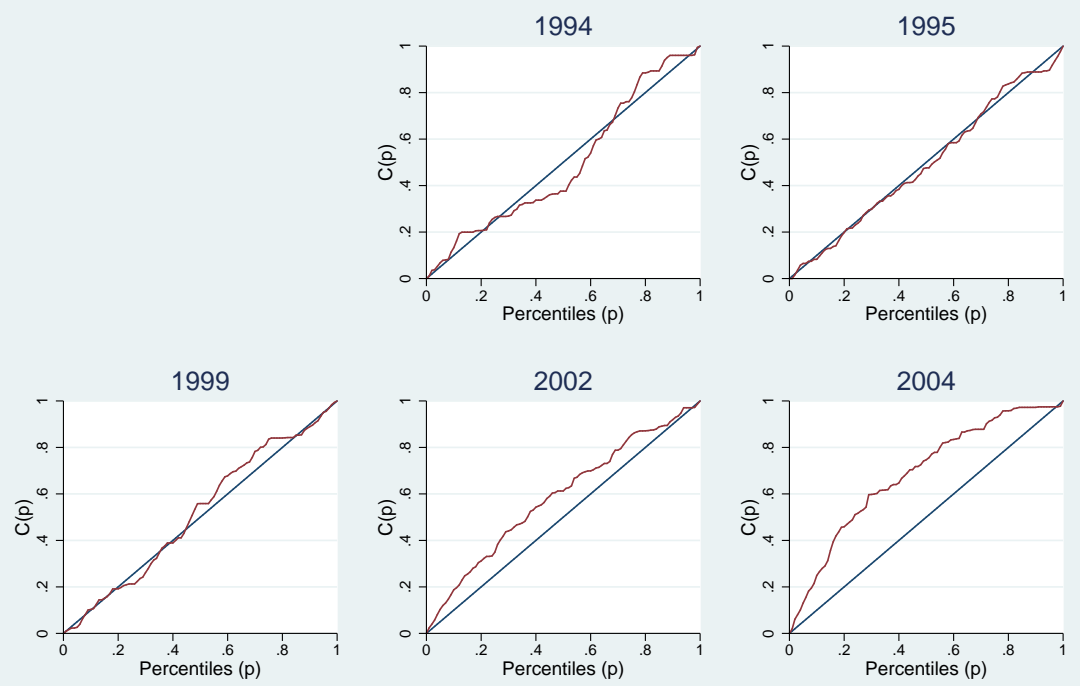

$45^{\circ}$ line

WArrearD

Figure 11: Concentration Curves - Wage Arrears by Year
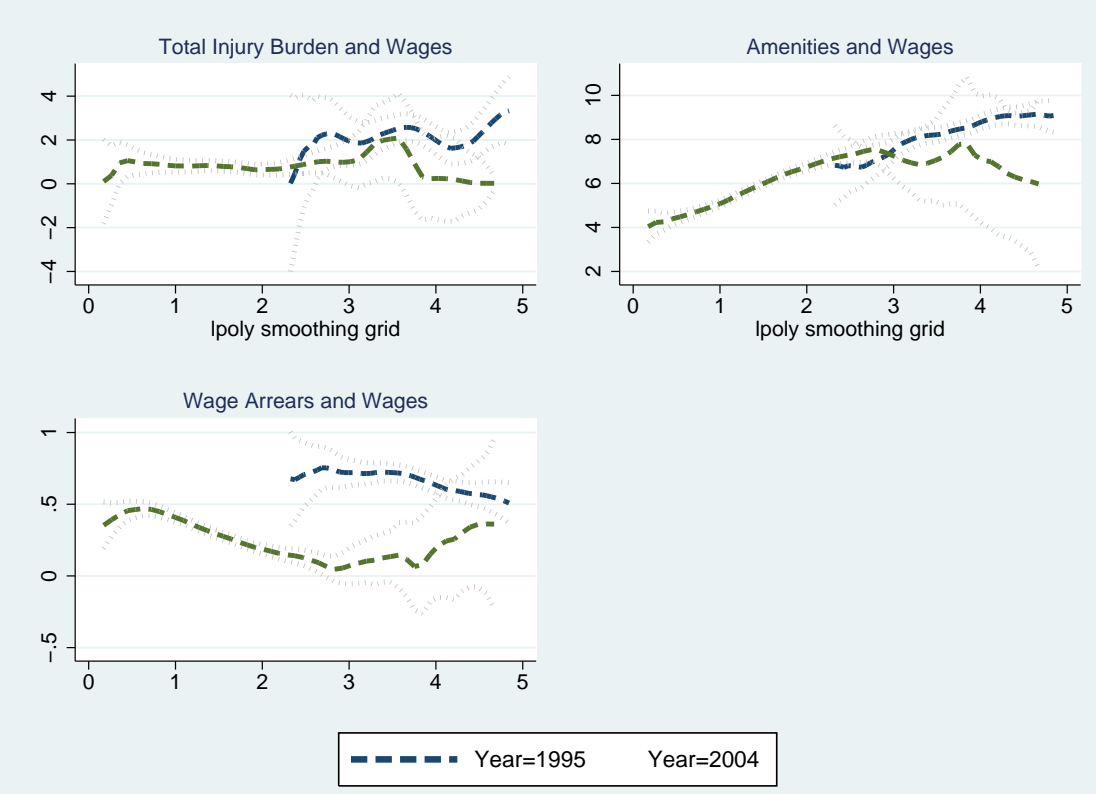

Figure 12: Nonparametric Lowess Smoothing Estimates (bandwidth=0.2) 
Table 1: Summary Statistics

\begin{tabular}{|c|c|c|c|c|c|}
\hline & 1995 & 1999 & 2000 & 2002 & 2004 \\
\hline \multirow[t]{2}{*}{ Wages } & 3.57 & 8.86 & 44.29 & 15.32 & 13.71 \\
\hline & [1.74] & [2.45] & [58.3] & {$[5.62]$} & [12.13] \\
\hline \multirow[t]{2}{*}{ Incidence of Injuries per $100 \mathrm{FTE}$} & 1.04 & 0.81 & 0.59 & 0.61 & 0.40 \\
\hline & {$[2.75]$} & [2.09] & {$[1.58]$} & {$[1.42]$} & [0.86] \\
\hline \multirow[t]{2}{*}{ Duration per Injury } & 3.10 & 3.80 & 3.35 & 3.16 & 1.73 \\
\hline & {$[3.23]$} & [7.02] & [4.85] & {$[2.63]$} & [3.66] \\
\hline Total Injury Burden per 100 FTE & 3.32 & 2.96 & 1.99 & 1.99 & 0.58 \\
\hline (Incidence*Duration) & [7.99] & {$[6.72]$} & {$[4.57]$} & [4.05] & [2.17] \\
\hline \multirow{2}{*}{ Number of shifts per day } & 2.15 & 2.28 & 2.13 & 2.17 & 2.17 \\
\hline & {$[0.95]$} & {$[1.27]$} & {$[1.00]$} & {$[0.95]$} & [0.93] \\
\hline \multirow[t]{2}{*}{ Total working hours } & 33.72 & 33.20 & 33.92 & 35.85 & 36.97 \\
\hline & {$[6.85]$} & {$[6.25]$} & {$[6.82]$} & {$[5.66]$} & [4.9] \\
\hline \multirow[t]{2}{*}{ Amenities Score } & 9.49 & 7.61 & 7.84 & 7.66 & 7.40 \\
\hline & {$[2.50]$} & {$[2.56]$} & {$[2.85]$} & [2.67] & [2.74] \\
\hline Difficulty paying wages & 0.71 & 0.76 & 0.63 & 0.43 & 0.20 \\
\hline Wage Arrears & 0.42 & 0.39 & 0.27 & 0.28 & 0.15 \\
\hline \multirow{2}{*}{$\%$ workers fully paid } & & & 45.77 & 73.72 & 81.98 \\
\hline & & & [47.39] & [42.43] & {$[37.5]$} \\
\hline \multirow[t]{2}{*}{$\%$ workers with wage arrears $>3$ mo } & & & 71.37 & 35.64 & 4.82 \\
\hline & & & [34.57] & [41.16] & [18.97] \\
\hline \multirow[t]{2}{*}{ Weeks of wage arrears } & 2.03 & 16.70 & 3.60 & & \\
\hline & [2.44] & [18.18] & [7.71] & & \\
\hline Housing provision & 0.86 & 0.71 & 0.64 & 0.52 & 0.38 \\
\hline Rent subsidy & 0.25 & 0.09 & 0.14 & 0.11 & 0.07 \\
\hline Rest houses & 0.74 & 0.75 & 0.70 & 0.68 & 0.70 \\
\hline Paid health expenditures & 0.38 & 0.29 & 0.32 & 0.38 & 0.33 \\
\hline Kindergarden subsisdies & 0.42 & 0.30 & 0.36 & 0.33 & 0.21 \\
\hline Loans & 0.88 & 0.77 & 0.82 & 0.84 & 0.85 \\
\hline Interest Free Loans & 0.36 & 0.20 & 0.27 & 0.30 & 0.35 \\
\hline Assistance on retirement & 0.88 & 0.65 & 0.63 & 0.65 & 0.65 \\
\hline Supplement pension & 0.07 & 0.08 & 0.08 & 0.14 & 0.12 \\
\hline Training & 0.82 & 0.59 & 0.63 & 0.63 & 0.62 \\
\hline Meals & 0.51 & 0.31 & 0.32 & 0.28 & 0.29 \\
\hline Transportation & 0.24 & 0.28 & 0.26 & 0.19 & 0.22 \\
\hline No observations & 507 & 660 & 773 & 1327 & 1945 \\
\hline
\end{tabular}


Table 2: Estimated Gini/Concentration Indices and Their Time Dynamics

\begin{tabular}{|c|c|c|c|c|}
\hline & 1995 & 1999 & 2002 & 2004 \\
\hline \multicolumn{5}{|c|}{ A. Concentration Indices } \\
\hline \multirow[t]{2}{*}{ Wages } & $0.1750 * *$ & $0.1424 * *$ & $0.1275 * *$ & $0.1526 * *$ \\
\hline & $(0.0000)$ & $(0.0093)$ & $(0.0054)$ & $(0.0055)$ \\
\hline \multirow[t]{2}{*}{ Total Injury Burden } & $0.4085 * *$ & $0.2402 *$ & $0.2172 * *$ & $-0.1587 *$ \\
\hline & $(0.0000)$ & $(0.0920)$ & $(0.0486)$ & $(0.0573)$ \\
\hline \multirow[t]{2}{*}{ Amenities Score } & $0.0094 * *$ & $0.0313 * *$ & $0.0537 * *$ & $0.0823 * *$ \\
\hline & $(0.0000)$ & $(0.0117)$ & $(0.0117)$ & $(0.0132)$ \\
\hline \multirow[t]{2}{*}{ Wage Arrears } & $0.0025 * *$ & -0.0327 & $-0.1759 * *$ & $-0.3715 * *$ \\
\hline & $(0.0000)$ & $(0.0522)$ & $(0.0466)$ & $(0.0502)$ \\
\hline \multicolumn{5}{|c|}{ B. Comparing Concentration Indices Over Time } \\
\hline \multirow{3}{*}{ Total Injury Burden } & $1995-2004$ & 1995-1999 & $1999-2002$ & $2004-2002$ \\
\hline & $-0.5916^{* *}$ & $-0.1927 *$ & -0.0229 & $-0.3760 * *$ \\
\hline & $(0.0573)$ & $(0.0920)$ & $(0.1040)$ & $(0.0751)$ \\
\hline \multirow[t]{2}{*}{ Amenities Score } & $0.0734 * *$ & $0.0225^{*}$ & 0.0224 & $0.0286+$ \\
\hline & $(0.0132)$ & $(0.0117)$ & $(0.0165)$ & $(0.0176)$ \\
\hline \multirow[t]{2}{*}{ Wage Arrears } & $-0.3802 * *$ & -0.0414 & $-0.1432 *$ & $-0.1956 * *$ \\
\hline & $(0.0502)$ & $(0.0522)$ & $(0.0700)$ & $(0.0685)$ \\
\hline
\end{tabular}

Note: $* * p<0.01, * p<0.05,+p<0.1$.

Table 3: Estimates of the Hybrid Multidimensional Inequality Index

\begin{tabular}{lcccc}
\hline \hline & 1995 & 1999 & 2002 & 2004 \\
\hline \multicolumn{1}{c}{ A. Multidimensional Inequality Estimates $(\lambda=0.5)$} \\
\hline Total (MDI) & 0.1215 & 0.1562 & 0.1081 & 0.0891 \\
Relative contribution of: & & & & \\
Wages & $9.57 \%$ & $40.63 \%$ & $13.98 \%$ & $22.15 \%$ \\
Total Safety Level & $3.48 \%$ & $0.93 \%$ & $6.12 \%$ & $0.76 \%$ \\
Amenities Score & $26.65 \%$ & $31.15 \%$ & $37.34 \%$ & $50.29 \%$ \\
Absence of Wage Arrears & $60.31 \%$ & $27.29 \%$ & $42.56 \%$ & $26.80 \%$ \\
\hline \multicolumn{1}{c}{ B. Multidimensional Inequality Estimates - Robustness check } \\
\hline Total (MDI) $(\lambda=0.0)$ & 0.0912 & 0.1142 & 0.0599 & 0.0672 \\
Total (MDI) $(\lambda=0.1)$ & 0.0973 & 0.1224 & 0.0693 & 0.0716 \\
Total (MDI) $(\lambda=0.5)$ & 0.1215 & 0.1562 & 0.1081 & 0.0891 \\
Total (MDI) $(\lambda=0.9)$ & 0.1457 & 0.1901 & 0.1468 & 0.1066 \\
Total (MDI) $(\lambda=1.0)$ & 0.1517 & 0.1985 & 0.1564 & 0.1110 \\
\hline \hline
\end{tabular}

Note: $* * p<0.01, * p<0.05,+p<0.1$. 
Table 4: Concentration Indices for Individual Amenities

\begin{tabular}{|c|c|c|c|}
\hline & 1995 & 2004 & $\overline{\text { Diff(1995-2004) }}$ \\
\hline \multirow[t]{2}{*}{ Housing provision } & $0.0491 * *$ & $0.1329 * *$ & $0.0838+$ \\
\hline & $(0.0142)$ & $(0.0463)$ & $(0.0485)$ \\
\hline \multirow[t]{2}{*}{ Rent subsidy } & 0.0079 & $0.2308 * *$ & $0.2228 *$ \\
\hline & $(0.0830)$ & $(0.0896)$ & $(0.1222)$ \\
\hline \multirow[t]{2}{*}{ Rest houses } & 0.0052 & $0.1048 * *$ & $0.0997 * *$ \\
\hline & $(0.0288)$ & $(0.0135)$ & $(0.0318)$ \\
\hline \multirow[t]{2}{*}{ Paid health expenditures } & -0.0444 & $0.2476 * *$ & $0.2920 * *$ \\
\hline & $(0.0681)$ & $(0.0452)$ & $(0.0817)$ \\
\hline \multirow[t]{2}{*}{ Kindergarden subsisdies } & 0.0708 & $0.3377 * *$ & $0.2669 * *$ \\
\hline & $(0.0643)$ & $(0.0710)$ & $(0.0958)$ \\
\hline \multirow[t]{2}{*}{ Loans } & -0.0175 & $0.0512 * *$ & $0.0687 * *$ \\
\hline & $(0.0230)$ & $(0.0083)$ & $(0.0245)$ \\
\hline \multirow[t]{2}{*}{ Interest Free Loans } & -0.0133 & $0.1262 * *$ & $0.1394+$ \\
\hline & $(0.0672)$ & $(0.0499)$ & $(0.0837)$ \\
\hline \multirow[t]{2}{*}{ Assistance on retirement } & 0.0061 & $0.0886^{* *}$ & $0.0825^{* *}$ \\
\hline & $(0.0185)$ & $(0.0200)$ & $(0.0273)$ \\
\hline \multirow[t]{2}{*}{ Supplement pension } & $0.3045^{* *}$ & $0.3563 * *$ & 0.0514 \\
\hline & $(0.0959)$ & $(0.0947)$ & $(0.1348)$ \\
\hline \multirow[t]{2}{*}{ Training } & 0.0088 & $0.0985 * *$ & $0.0897 * *$ \\
\hline & $(0.0206)$ & $(0.0255)$ & $(0.0328)$ \\
\hline \multirow[t]{2}{*}{ Meals } & -0.0219 & 0.0757 & -0.0976 \\
\hline & $(0.0529)$ & $(0.0630)$ & $(0.0823)$ \\
\hline \multirow[t]{2}{*}{ Transportation } & 0.0207 & $0.1837 * *$ & $0.1630+$ \\
\hline & $(0.0758)$ & $(0.0697)$ & $(0.1030)$ \\
\hline
\end{tabular}

Notes: (i) Robust standard errors in parentheses, (ii) $* * p<0.01, * p<0.05,+p<0.1$, (iii) significance levels for individual years relates to the difference with equal distribution, while significance levels for the difference relates to the difference in the concentration indices over the relevant time period. 
Table 5: Changes in the Distribution of Firms' Characteristics Across Wage Distribution

\begin{tabular}{|c|c|c|c|}
\hline & 1995 & 2004 & Diff(1995-2004) \\
\hline \multirow{2}{*}{ Size } & 0.0988 & $0.3991 * *$ & $0.3003 * *$ \\
\hline & $(0.0648)$ & $(0.0529)$ & $(0.0837)$ \\
\hline \multirow[t]{2}{*}{ State ownership } & 0.0378 & 0.0378 & -0.00001 \\
\hline & $(0.0623)$ & $(0.0882)$ & $(0.1080)$ \\
\hline \multirow[t]{2}{*}{ Export status } & -0.0241 & $0.1399 * *$ & $0.1640+$ \\
\hline & $(0.0847)$ & $(0.0466)$ & $(0.0966)$ \\
\hline \multirow[t]{2}{*}{ Monopoly status } & $-0.1843 * *$ & -0.0607 & 0.1236 \\
\hline & $(0.0684)$ & $(0.0604)$ & $(0.0913)$ \\
\hline \multirow[t]{2}{*}{ Share of female workers } & $-0.0653 * *$ & $-0.0810 * *$ & -0.0157 \\
\hline & $(0.0163)$ & $(0.0083)$ & $(0.0183)$ \\
\hline \multirow[t]{2}{*}{ Blue-collar worker's share } & 0.0035 & $0.0138 * *$ & 0.0103 \\
\hline & $(0.0057)$ & $(0.0034)$ & $(0.0066)$ \\
\hline \multirow[t]{2}{*}{ Has temporary workers } & 0.0003 & 0.0108 & 0.0104 \\
\hline & $(0.0474)$ & $(0.0096)$ & $(0.0483)$ \\
\hline \multicolumn{4}{|l|}{ Industrial sectors } \\
\hline \multirow[t]{2}{*}{ Energy } & $0.6557 * *$ & $0.2843 * *$ & $-0.3714 * *$ \\
\hline & $(0.0674)$ & $(0.0684)$ & $(0.0960)$ \\
\hline \multirow[t]{2}{*}{ Metallurgy } & 0.1159 & $0.3778 * *$ & 0.2619 \\
\hline & $(0.1600)$ & $(0.0810)$ & $(0.1790)$ \\
\hline \multirow[t]{2}{*}{ Engineering } & $-0.1535^{*}$ & $-0.1883 * *$ & -0.0348 \\
\hline & $(0.0686)$ & $(0.0606)$ & $(0.0915)$ \\
\hline \multirow[t]{2}{*}{ Chemicals } & -0.1894 & 0.0050 & 0.1943 \\
\hline & $(0.1798)$ & $(0.1169)$ & $(0.2145)$ \\
\hline \multirow[t]{2}{*}{ Wood and Paper } & $-0.3541 * *$ & $-0.2492 * *$ & 0.1049 \\
\hline & $(0.1213)$ & $(0.0742)$ & $(0.1421)$ \\
\hline \multirow[t]{2}{*}{ Construction materials } & -0.0836 & -0.1557 & -0.0721 \\
\hline & $(0.1076)$ & $(0.0673)$ & $(0.1269)$ \\
\hline \multirow[t]{2}{*}{ Light industry } & -0.0583 & $-0.3466 * *$ & $-0.2883 * *$ \\
\hline & $(0.0998)$ & $(0.0676)$ & $(0.1206)$ \\
\hline \multirow[t]{2}{*}{ Food processing } & 0.0260 & $-0.2112 * *$ & $-0.2371 * *$ \\
\hline & $(0.0801)$ & $(0.0448)$ & $(0.0918)$ \\
\hline
\end{tabular}

See notes to Table 4. 


\section{Appendix A}

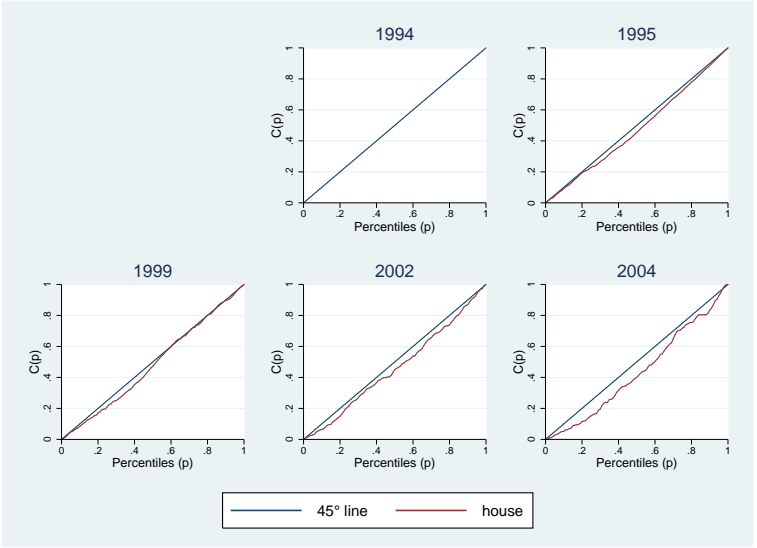

Figure A.1: Distribution of Housing Provision by Year

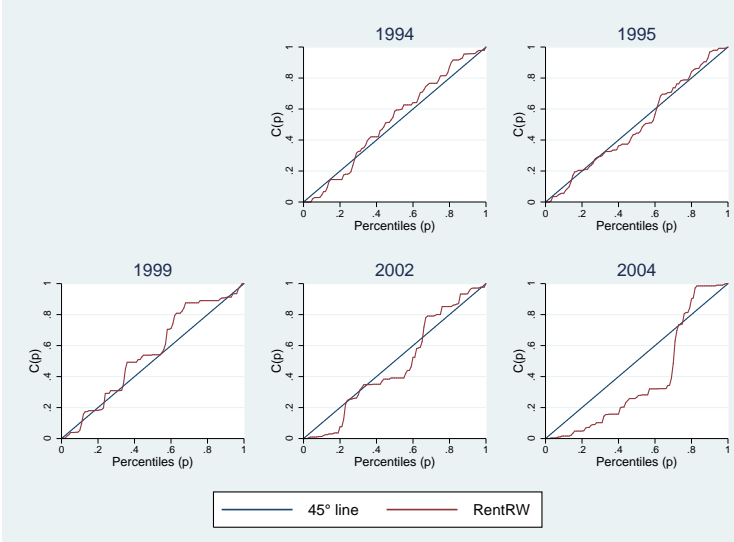

Figure A.2: Distribution of Subsidized Rent Provision by Year 


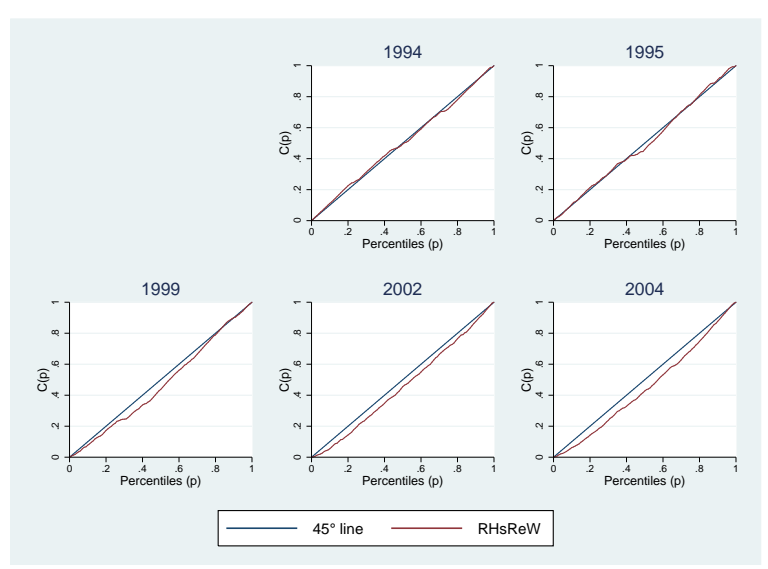

Figure A.3: Distribution of Rest Houses Provision by Year

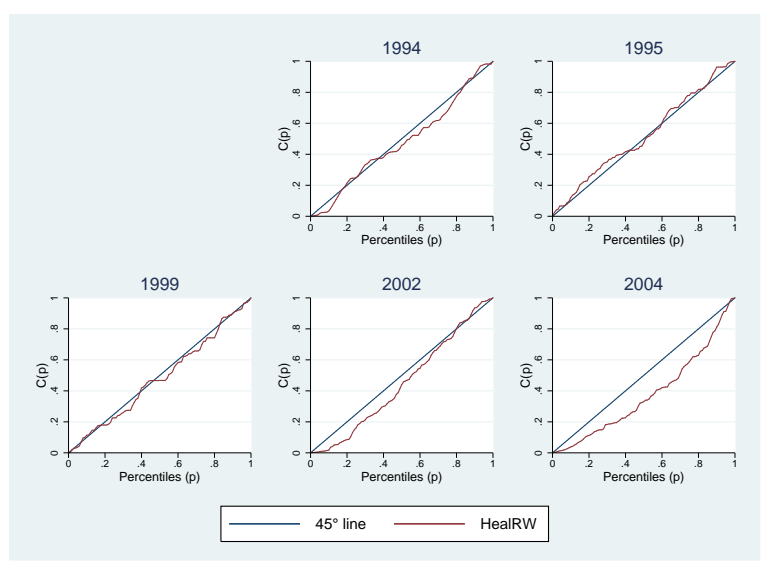

Figure A.4: Distribution of Health Services Provision by Year

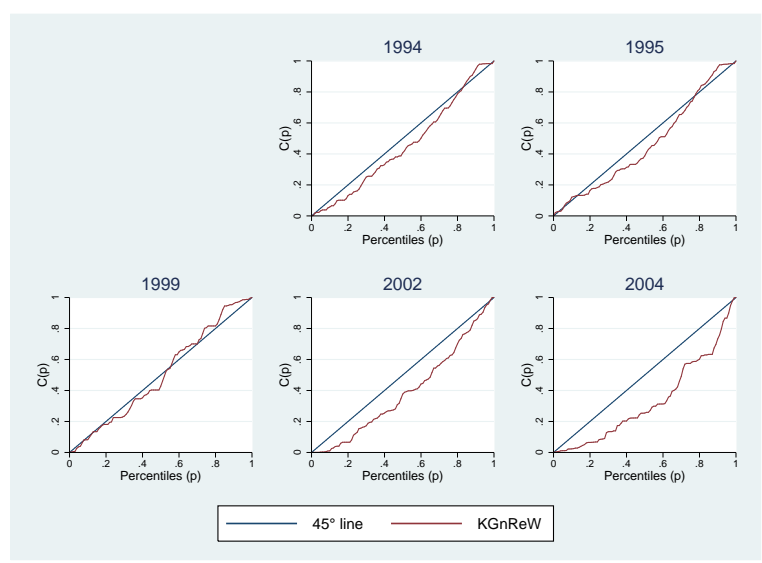

Figure A.5: Distribution of Kindergarden Subsidies Provision by Year 


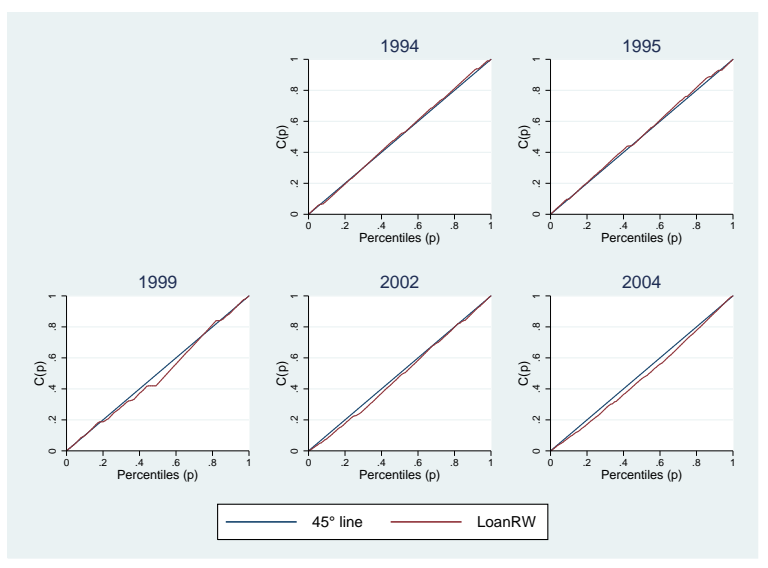

Figure A.6: Distribution of Loan Provision by Year

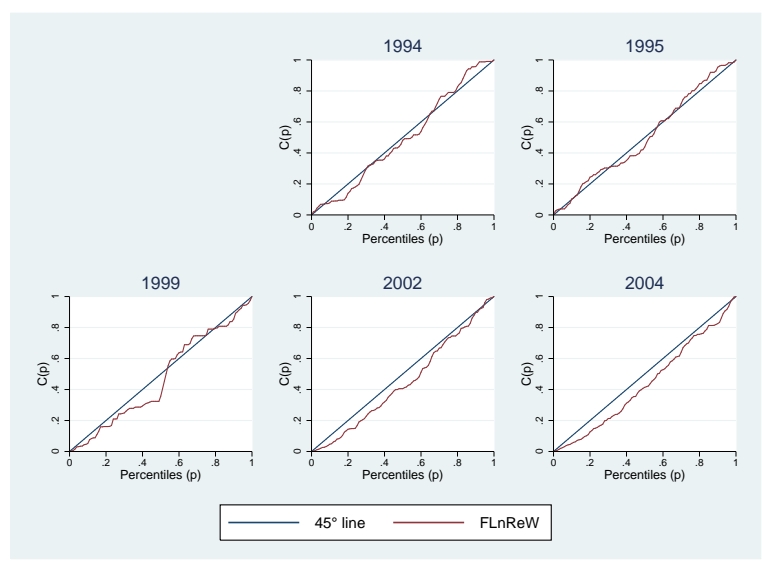

Figure A.7: Distribution of Interest-free Loan Provision by Year

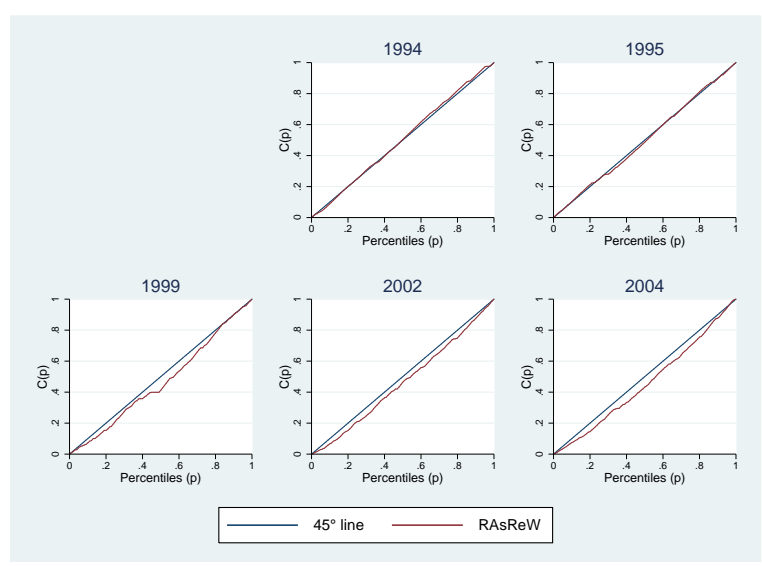

Figure A.8: Distribution of Assistance on Retirement Provision by Year 


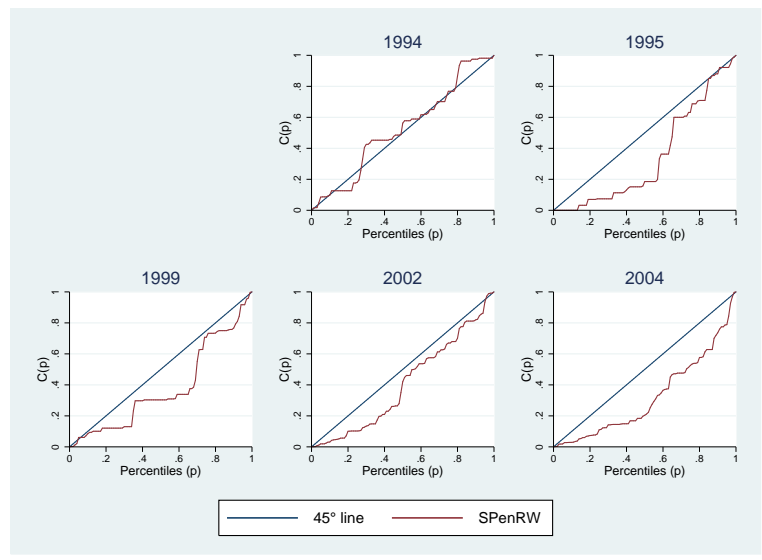

Figure A.9: Distribution of Supplementary Pension Provision by Year

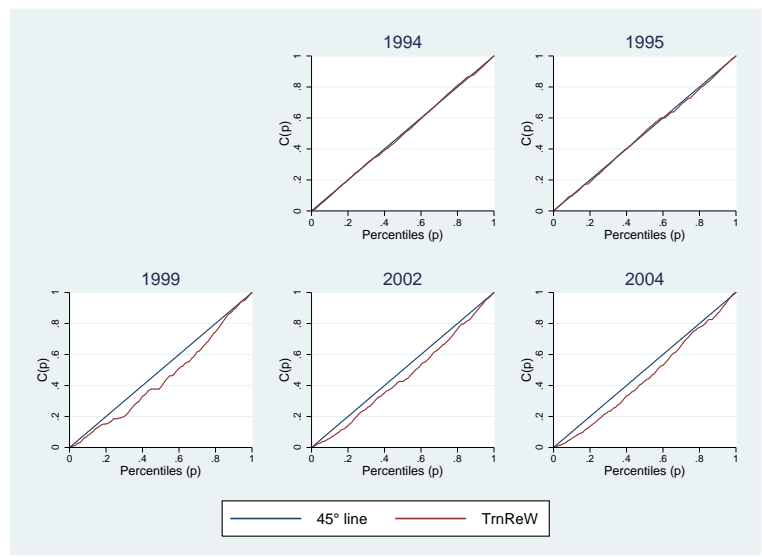

Figure A.10: Distribution of Training Provision by Year

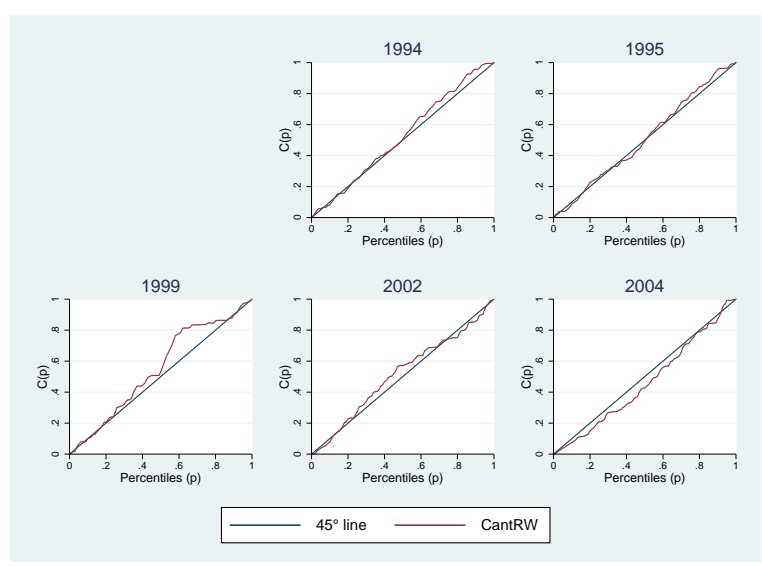

Figure A.11: Distribution of Meal Subsidies Provision by Year 


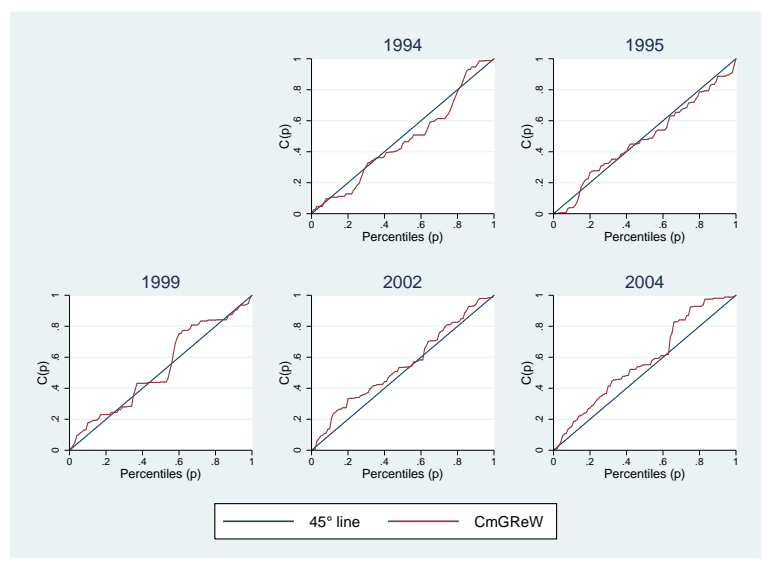

Figure A.12: Distribution of Consumer Goods Subsidies Provision by Year

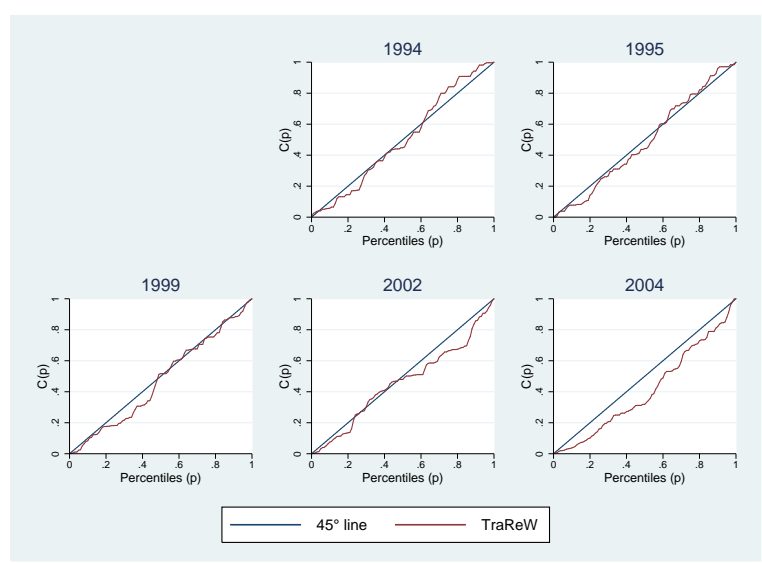

Figure A.13: Distribution of Transportation Subsidies Provision by Year 
Appendix B 
Table B.1: Firms' Characteristics Over Sample Period

\begin{tabular}{|c|c|c|c|c|c|c|c|c|}
\hline \multirow[b]{2}{*}{ year } & \multicolumn{2}{|c|}{ 1st quartile } & \multicolumn{2}{|c|}{ 2nd quartile } & \multicolumn{2}{|c|}{ 3rd quartile } & \multicolumn{2}{|c|}{ 4th quartile } \\
\hline & 1995 & 2004 & 1995 & 2004 & 1995 & 2004 & 1995 & 2004 \\
\hline \multirow[t]{2}{*}{ Number of workers } & $2530 * * *$ & $652 * * *$ & $2024 * * *$ & $943 * * *$ & $3030 * * *$ & $2360 * * *$ & $2737 * * *$ & $6252 * * *$ \\
\hline & [2268] & [766] & [2134] & [1189] & [2923] & [2460] & [2200] & [7073] \\
\hline \multirow[t]{2}{*}{ State ownership } & $0.4208 * * *$ & $0.1260 * * *$ & $0.3845 * * *$ & $0.1337 * * *$ & $0.4465 * * *$ & $0.1423 * * *$ & $0.3742 * * *$ & $0.1419 * * *$ \\
\hline & {$[0.4956]$} & {$[0.3322]$} & {$[0.4884]$} & {$[0.3407]$} & {$[0.4991]$} & {$[0.3498]$} & {$[0.4859]$} & {$[0.3493]$} \\
\hline \multirow[t]{2}{*}{ Workers' ownership } & $0.0000 * * *$ & $8.6994 * * *$ & $0.0000 * * *$ & $7.5473 * * *$ & $0.0000 * * *$ & $11.5369 * * *$ & $0.0000 * * *$ & $6.9935 * * *$ \\
\hline & {$[0.0000]$} & {$[20.1875]$} & [0.0000] & [17.3762] & {$[0.0000]$} & [23.8187] & {$[0.0000]$} & [16.1267] \\
\hline \multirow[t]{2}{*}{ Export } & 16.9767 & 16.6420 & $15.5510 * * *$ & $21.1090 * * *$ & $16.5257 * * *$ & $25.2181 * * *$ & $13.2542 * * *$ & $32.4118 * * *$ \\
\hline & [16.1848] & [28.9446] & {$[17.4568]$} & [27.3883] & [16.9978] & [27.5827] & [18.1903] & [33.6179] \\
\hline \multirow[t]{2}{*}{ Monopoly } & $0.3627 * * *$ & $0.2067 * * *$ & $0.4551 * * *$ & $0.2524 * * *$ & $0.3451 * *$ & $0.2575^{* *}$ & 0.2287 & 0.2455 \\
\hline & {$[0.4827]$} & {$[0.4053]$} & {$[0.5000]$} & {$[0.4348]$} & {$[0.4773]$} & {$[0.4377]$} & {$[0.4217]$} & {$[0.4308]$} \\
\hline \multirow[t]{2}{*}{ Share of social costs } & 8.2376 & 7.5487 & $7.4893 * *$ & $8.8322 * *$ & $6.0384 * *$ & $7.4260 * *$ & $5.3023 * *$ & $7.0360 * *$ \\
\hline & {$[5.6316]$} & {$[7.8070]$} & {$[5.5671]$} & {$[6.7954]$} & {$[6.0731]$} & {$[5.6670]$} & {$[4.8681]$} & {$[7.0454]$} \\
\hline \multirow[t]{2}{*}{ Share of female workers } & 50.3024 & 50.2191 & $52.1682 * *$ & $48.5068 * *$ & 44.9346 & 44.8617 & $45.7409 * * *$ & $35.0524 * * *$ \\
\hline & {$[15.2951]$} & {$[20.8875]$} & {$[15.5015]$} & {$[19.9516]$} & [15.2933] & [17.1906] & {$[15.6424]$} & {$[13.4435]$} \\
\hline \multirow[t]{2}{*}{ Share of blue-colar workers } & $80.0893 * * *$ & $73.0285^{* * *}$ & $79.2153 * * *$ & $74.5574 * * *$ & $80.5710 * * *$ & $73.0638 * * *$ & $81.3419 * * *$ & $76.7429 * * *$ \\
\hline & [6.8069] & {$[10.6638]$} & [6.8827] & {$[12.6879]$} & {$[5.6641]$} & [11.6184] & [6.6222] & [9.1264] \\
\hline \multirow[t]{2}{*}{ Any temporary workers } & $0.6180 * * *$ & $0.7387 * * *$ & $0.5292 * * *$ & $0.8526 * * *$ & $0.5272 * * *$ & $0.9305^{* * *}$ & $0.4745 * * *$ & $0.9094 * * *$ \\
\hline & {$[0.4878]$} & {$[0.4398]$} & {$[0.5011]$} & {$[0.3548]$} & {$[0.5013]$} & {$[0.2546]$} & {$[0.5013]$} & {$[0.2873]$} \\
\hline
\end{tabular}


Table B.2: Industrial Structure Over Sample Period

\begin{tabular}{|c|c|c|c|c|c|c|c|c|}
\hline \multirow[b]{2}{*}{ year } & \multicolumn{2}{|c|}{ 1st quartile } & \multicolumn{2}{|c|}{ 2nd quartile } & \multicolumn{2}{|c|}{ 3rd quartile } & \multicolumn{2}{|c|}{ 4th quartile } \\
\hline & 1995 & 2004 & 1995 & 2004 & 1995 & 2004 & 1995 & 2004 \\
\hline indsec $==$ metals & $0.0939 * * *$ & $0.0201 * * *$ & 0.0581 & 0.0528 & $0.2884 * * *$ & $0.1461 * * *$ & $0.0705 * * *$ & $0.2968 * * *$ \\
\hline & {$[0.2928]$} & {$[0.1405]$} & {$[0.2348]$} & {$[0.2238]$} & {$[0.4548]$} & {$[0.3536]$} & {$[0.2570]$} & {$[0.4573]$} \\
\hline indsec $==$ engineering & $0.4512 * * *$ & $0.2381 * * *$ & $0.4467 * *$ & $0.3496 * *$ & 0.3303 & 0.2995 & $0.3274 * * *$ & $0.1667 * * *$ \\
\hline & {$[0.4996]$} & {$[0.4264]$} & {$[0.4991]$} & {$[0.4773]$} & {$[0.4722]$} & {$[0.4585]$} & {$[0.4712]$} & {$[0.3731]$} \\
\hline indsec $==$ chemicals & 0.1290 & 0.1684 & $0.1847 * * *$ & $0.0430 * * *$ & 0.0674 & 0.0842 & 0.0895 & 0.1065 \\
\hline & {$[0.3365]$} & {$[0.3746]$} & {$[0.3896]$} & {$[0.2032]$} & {$[0.2517]$} & {$[0.2779]$} & {$[0.2866]$} & [0.3089] \\
\hline indsec==wood $\&$ paper & 0.1194 & 0.0885 & 0.0299 & 0.0458 & 0.0264 & 0.0497 & 0.0228 & 0.0220 \\
\hline & {$[0.3255]$} & {$[0.2843]$} & [0.1709] & [0.2092] & {$[0.1608]$} & {$[0.2176]$} & [0.1497] & [0.1469] \\
\hline indsec==building mat. & 0.0469 & 0.0447 & 0.0733 & 0.0593 & 0.0612 & 0.0445 & 0.0295 & 0.0351 \\
\hline & {$[0.2122]$} & {$[0.2067]$} & {$[0.2616]$} & {$[0.2363]$} & {$[0.2406]$} & {$[0.2065]$} & [0.1699] & {$[0.1842]$} \\
\hline indsec==light ind. & $0.0631 * * *$ & $0.1963 * * *$ & $0.1121 * *$ & $0.1759 * *$ & 0.0777 & 0.0756 & $0.1154 * * *$ & $0.0312 * * *$ \\
\hline & {$[0.2441]$} & {$[0.3976]$} & {$[0.3167]$} & {$[0.3812]$} & {$[0.2688]$} & {$[0.2646]$} & {$[0.3208]$} & {$[0.1741]$} \\
\hline indsec $==$ food proc & $0.0910 * * *$ & $0.2240 * * *$ & $0.0939 * * *$ & $0.2214 * * *$ & $0.0868 * *$ & $0.1623 * *$ & 0.1289 & 0.0851 \\
\hline & {$[0.2888]$} & {$[0.4173]$} & {$[0.2928]$} & {$[0.4156]$} & {$[0.2827]$} & {$[0.3691]$} & {$[0.3364]$} & {$[0.2793]$} \\
\hline indsec $==$ other & $0.0024 *$ & $0.0188 *$ & $0.0001 * *$ & $0.0216 * *$ & 0.0022 & 0.0142 & 0.0258 & 0.0195 \\
\hline & [0.0492] & {$[0.1360]$} & {$[0.0102]$} & {$[0.1456]$} & {$[0.0470]$} & [0.1184] & [0.1592] & {$[0.1385]$} \\
\hline
\end{tabular}




\section{Appendix C}

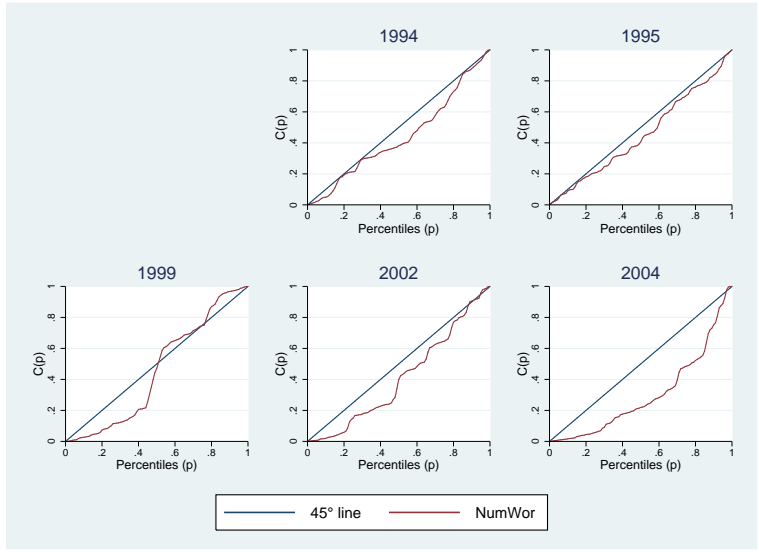

Figure C.1: Distribution of Workforce Size by Year

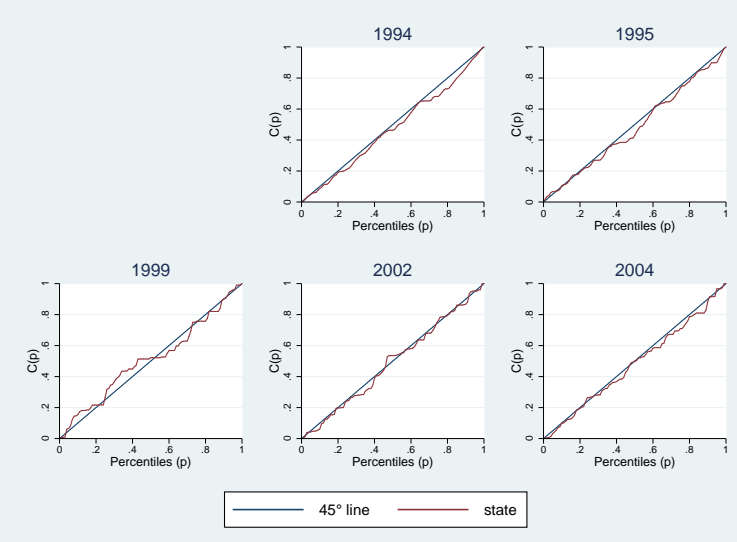

Figure C.2: Distribution of State Ownership by Year 


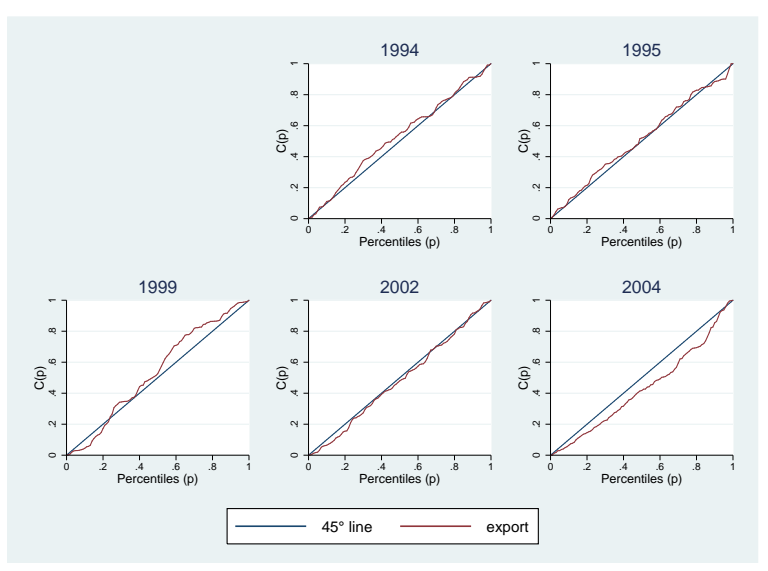

Figure C.3: Distribution of Export Status by Year

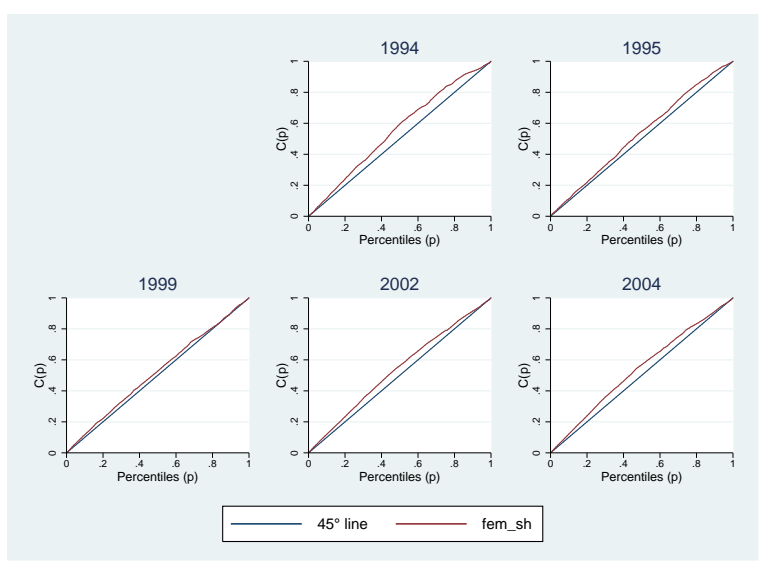

Figure C.4: Distribution of Share of Females by Year

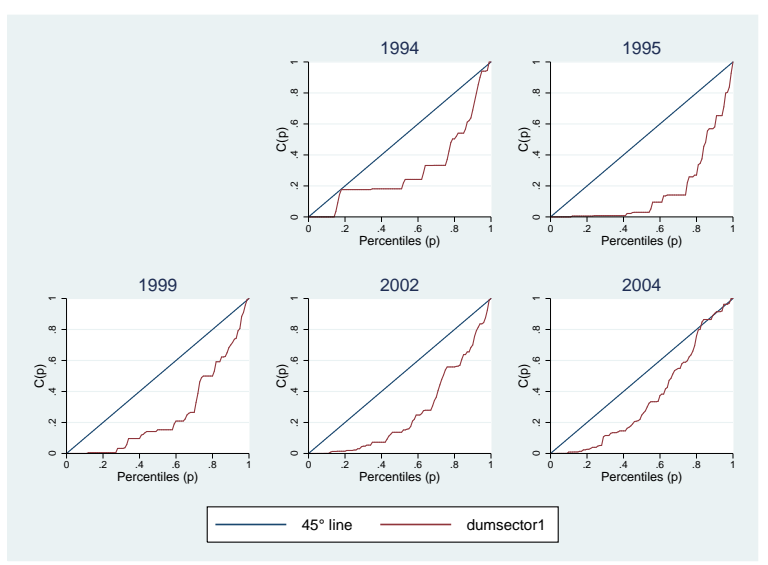

Figure C.5: Distribution of Energy Sector by Year 


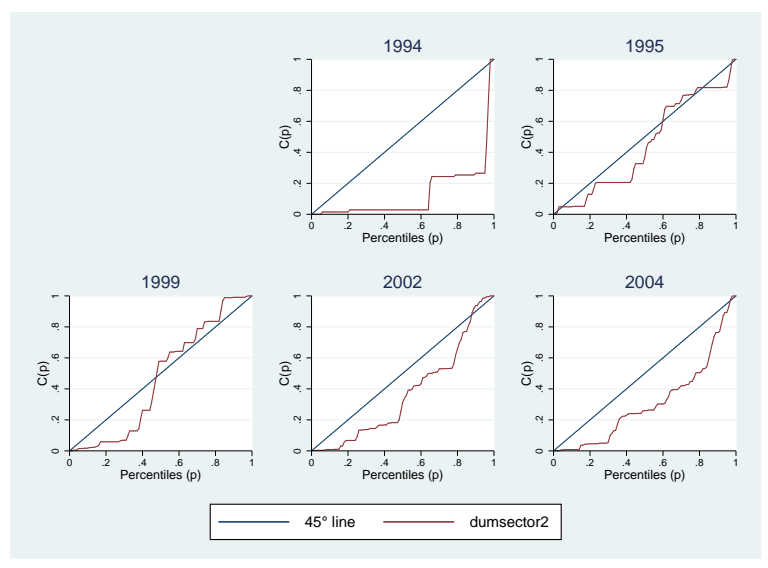

Figure C.6: Distribution of Metals Sector by Year

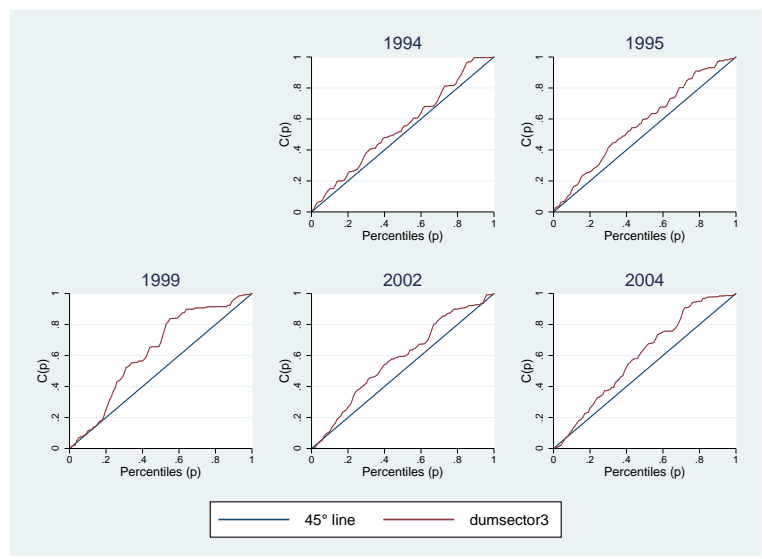

Figure C.7: Distribution of Engineering Sector by Year

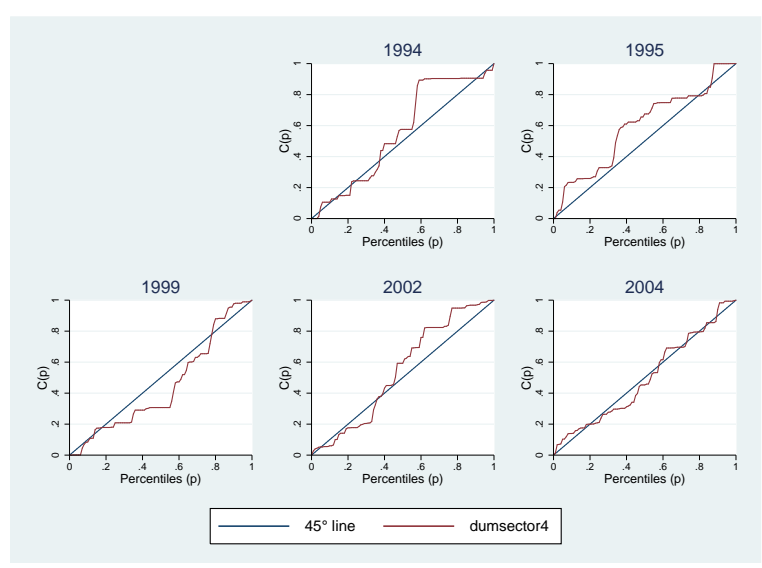

Figure C.8: Distribution of Chemicals Sector by Year 


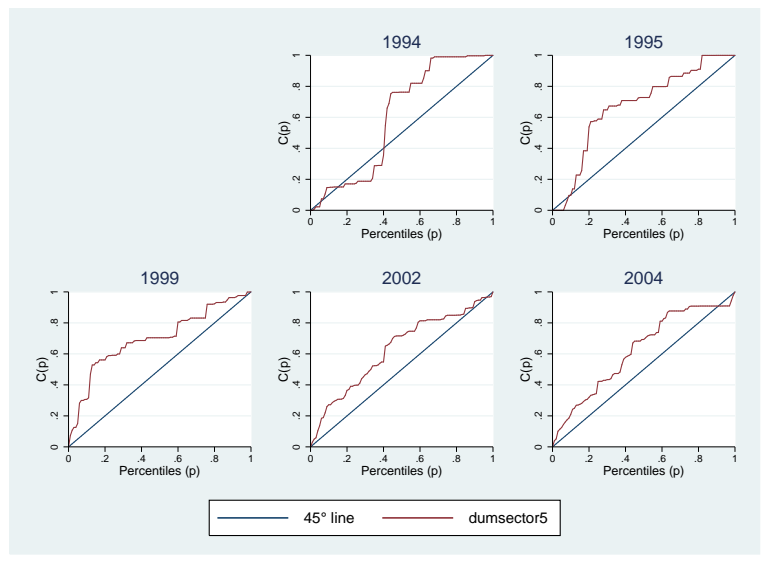

Figure C.9: Distribution of Wood and Paper Sector by Year

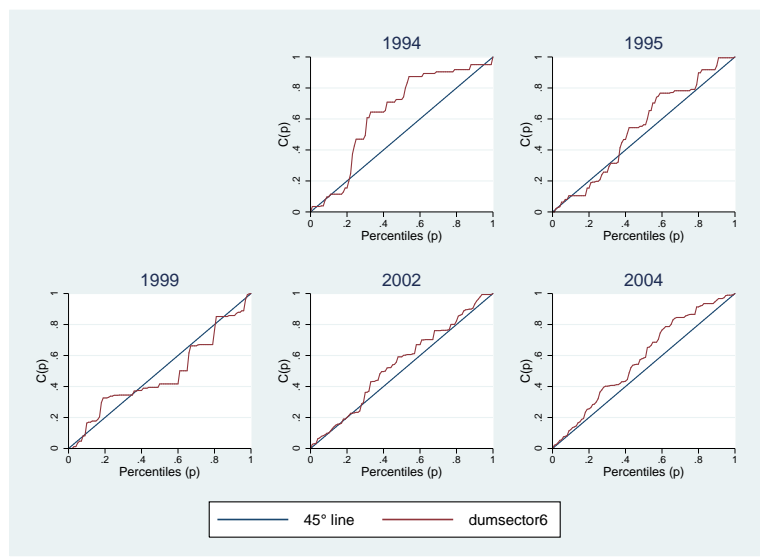

Figure C.10: Distribution of Construction Materials Sector by Year

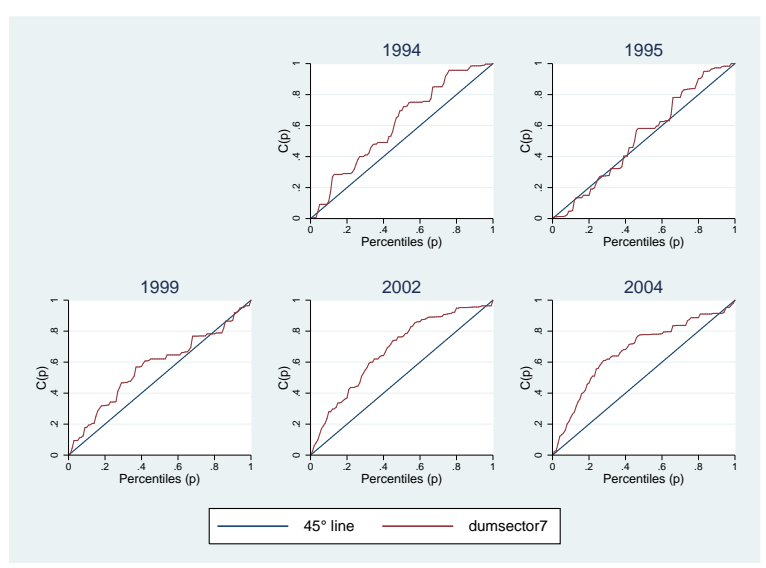

Figure C.11: Distribution of Light Industry Sector by Year 


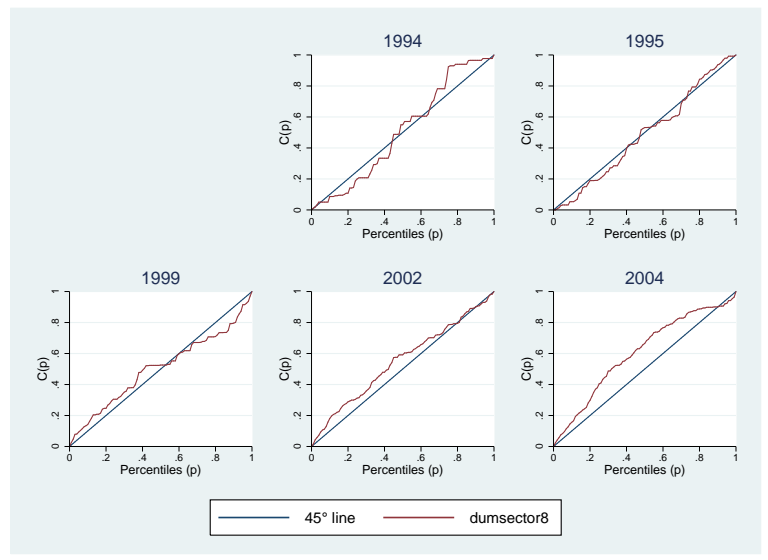

Figure C.12: Distribution of Food Processing Sector by Year 